ALEXANDRIA

SCIENCE EXCHANGE JOURNAL

\title{
Evaluation of Different Bread Wheat Genotypes for Drought Tolerance under Sandy Soil Conditions by Canopy Temperature and Excised Leaf Water Loss Techniques
}

\author{
El-Nakhlawy F.S ${ }^{1}$; M.M. Saadalla, M.S.S Badran ${ }^{2}$ and K.El-Sayed Amer ${ }^{1}$
}

\begin{abstract}
Two field experiments were conducted at the Experimental Farm of Damanhour Faculty of Agriculture, at El- Boustan, Damanhour University, Egypt during 2003/2004 and 2004/2005 winter growing seasons. This study aimed to evaluate sixteen bread wheat genotypes (locals and introductions) for drought tolerance under newly reclaimed area by two techniques; i.e., the canopy temperature (Tc) and the excised -leaf water loss (ELWL); and to compare these techniques with grain yield and kernel weight susceptibility indices. The study layout was a split- plot design, with four replicates. Three soil moisture levels of 25,55 and $85 \%$ of plant available water (AW) were allocated to the main-plots, whereas, the wheat genotypes were randomly assigned to the sub plots.
\end{abstract}

The obtained results showed that $\mathrm{Tc}$ ranged from 17.3 ${ }^{\circ} \mathrm{C}$, at $85 \% \mathrm{AW}$, to $22.4{ }^{\circ} \mathrm{C}$ at $25 \%$, AW in the first season, and from $16.7^{\circ} \mathrm{C}$, at $85 \% \mathrm{AW}$,to $18.7^{\circ} \mathrm{C}$ at $25 \%$ $\mathrm{AW}$ in the second season. The local cultivar, Sids 7 , had the warmest means of $\mathrm{Tc}\left(23.7^{\circ} \mathrm{C}\right)$ and $\left(19.4^{\circ} \mathrm{C}\right)$ at $25 \%$ AW in the first and second season, respectively. ELWL ranged from $58.5 \%$, at $85 \% \mathrm{AW}$, to $45.8 \%$, at $25 \% \mathrm{AW}$, in the first seasons, whereas, it ranged from $44.3 \%$, at $85 \%$ $\mathrm{AW}$, to $36.4 \%$, at $25 \% \mathrm{AW}$, in the second season. The local cultivar, Sakha 61, had the minimum means for ELWL $(32.4 \%)$ and $(32.8 \%)$ in the first and second seasons, respectively.

The number of days to both heading and maturity declined with lowering soil moisture. An average delay of about three days in both heading and maturity was recorded between the most abundant soil moisture and the most stressed level of soil moisture in both seasons. Sakha 61 cultivar was the earliest genotype for heading, in the first season, and maturity in both seasons, while, Sids 7 was the earliest genotype for heading, in the second season, under the least and the most stressed environments. The average of grain yield for the two growing seasons significantly decreased from 5.38 tons/ha, in the most abundant soil moisture of $85 \% \mathrm{AW}$, to 3.84 tons/ha in the most stressed soil moisture level of $25 \%$ AW. Sakha 69 local cultivar and introduced Line 7 gave the highest means for grain yield (5.99 and 6.38 tons/ha ) at $85 \% \mathrm{AW}$ in the first and second seasons, respectively.

Kernel weight significantly decreased from $53.65 \mathrm{mg}$, in the most abundant soil moisture of $85 \% \mathrm{AW}$, to 46.20 $\mathrm{mg}$ in the most stressed soil moisture level of $25 \% \mathrm{AW}$, over both seasons. The local cultivars, Gemmiza 7 and Gemmiza 9, recorded the highest means for kernel weight $(59.0 \mathrm{mg})$ in the first season, while, Sakha 61 recorded the highest mean $63.3 \mathrm{mg}$ in the second season at $85 \% \mathrm{AW}$. There was an insignificant negative correlation between Tc and both grain yield susceptibility index (Sy) and kernel weight susceptibility index (Sk) in the first season. However, there was a significant positive correlation, in the second season, between both (Sk and ELWL) and (Sy and ELWL), while, there was a nonsignificant correlation in the first season.

Key words: Wheat genotypes; Evaluation; Drought Tolerance: Canopy Temperature; Excised Leaf Water Loss; Plant Available Water (AW); Techniques.

\section{INTRODUCTION}

Wheat is the most important winter crop in Egypt. Increasing wheat local productivity is a national target to decrease the gap between consumption and production. The total growing area of 1.26 million hectares produced about 8.14 million tons, with an average of 6.5 tons/ha. Wheat planted area, out of the Nile Valley, was estimated by about 0.31 million hectares $(25 \%$ from total planted area), produced about 0.66 million tons ( $8 \%$ of the total production) with an average of 2.1 tons/ha (32\% of the national average, Journal of Agricultural Statistics, 2009).

Decreasing both area and productivity of wheat, out of the Nile Valley, may be due to a number of factors; i.e., limited water supply, drought conditions and poor sandy soil of nutrient elements. Drought is considered among the most critical conditions for productivity in such area. Water management is one of the most important factors affect growth and productivity in such

\footnotetext{
${ }^{1}$ Crop Sci. Dept., Fac. of Agric. El- Shatby, Alex. Univ., Egypt

${ }^{2}$ Crop Sci. Dept., Fac. of Agric., Damanhour Univ., Egypt

Received April 19, 2011, Accepted May 12, 2011
} 
area. Hence, developing wheat cultivars, that use available water more efficiently with high drought tolerance, is a major goal for increasing wheat productivity in such regions.

Suitable screening techniques are a major requirement for evaluation of drought-tolerant wheat cultivars. These techniques might be dependent on identification of relevant physiological traits. Canopy temperature, as measured by infrared thermometers, was suggested as a screening tool (Losavio et al., 1984). Furthermore, excised - leaf water loss has been used for the same screening purpose (Dedio, 1975)

This investigation aimed to evaluate sixteen wheat cultivars and lines (locals and introduced) for drought tolerance under three water regime treatments in a newly reclaimed area.

\section{MATERIALS AND METHODS}

The present study was conducted at El - Boustan Experimental Farm, Faculty of Agriculture, Damanhour University, Egypt. Two field experiments were carried out in the two successive winter seasons of 2003/2004 and 2004 /2005. Soil samples, taken from the experimental site, were mechanically and chemically analyzed (Black et al., 1965) and are presented in Table (1). The results of analysis presented in Table (1), showed that the soil was characterized as sandy and poor in organic matter and plant nutrients.

Sixteen wheat genotypes, included nine local cultivars, one local line and six introduced Mexican lines, shown in Table (2), were evaluated for drought tolerance in this study by both canopy temperature (Tc) and excised leaf water loss (ELWL) techniques. Three different water-regime treatments were applied in both seasons of this study, based on the soil available water. Field capacity of irrigation water, for the experimental site, was determined by using tension table at tension of $1 / 3$ bar. Permanent wilting point was measured, using the pressure membrane device in the laboratory. Soil samples of the experimental site were placed in the pressure cooker apparatus on a porous plate and equilibrated with an applied pressure of 15 bars. The plant available water (AW) of soil is defined as the amount of water retained in the soil reservoir that can be removed by plants. This can be calculated as the difference in water content between field capacity and permanent witting point, as follows: $(\mathrm{AW}=$ soil water content at a field capacity-soil water content at permanent wilting point). Figure(1) illustrates the relationship between water content (\%) and water potential (bar) to identify the irrigation treatments.

Three different water-regime treatments, based on AW (25, 55 and 85\%), were planned in both seasons. In the most stress treatment, 25\% AW, the irrigation flooding was not applied till soil available water was depleted to $25 \% \mathrm{AW}$, while, in the two other treatments of 55 and $85 \%$ AW, the soil moisture was kept above 55 and $85 \%$ AW, respectively. The soil moisture content was planned to be kept at the three levels of 25 , 55 and $85 \%$ AW until the yellow ripe stage of wheat. However, the water -regime treatments of 55 and $85 \%$ AW were applicable in both seasons, while, the water regime of $25 \% \mathrm{AW}$ was only applicable in the second season due to the relative heavy precipitation in the first growing season (Fig. 2).

Table 1. Some physical and chemical soil properties of EL-Boustan Experimental Farm

\begin{tabular}{|c|c|}
\hline Soil properties & Value \\
\hline $\mathrm{pH}, 1: 2.5$ soil :water ratio & 7.7 \\
\hline $\mathrm{EC}\left(\mathrm{dsm}^{-1}\right)$ & 1.85 \\
\hline \multicolumn{2}{|l|}{ Soluble cations (meq/l) } \\
\hline $\mathrm{Ca}^{++}$ & 6.1 \\
\hline $\mathrm{Mg}^{++}$ & 3.0 \\
\hline $\mathrm{Na}^{+}$ & 9.5 \\
\hline $\mathrm{K}^{+}$ & 0.1 \\
\hline \multicolumn{2}{|l|}{ Soluble anions (meq/l) } \\
\hline $\mathrm{CO}_{3}^{--}$ & 0 \\
\hline $\mathrm{HCO}_{3}^{-}$ & 1.8 \\
\hline $\mathrm{Cl}^{-}$ & 9.8 \\
\hline $\mathrm{SO}_{4}^{--}$ & 7.1 \\
\hline O.M.(\%) & 0.04 \\
\hline SAR & 4.45 \\
\hline $\mathrm{CaCO}_{3}$ & 0.3 \\
\hline \multicolumn{2}{|l|}{ Practical size analysis (\%) } \\
\hline Sand & 97.6 \\
\hline Silt & 1.5 \\
\hline Clay & 0.9 \\
\hline Texture & Sand \\
\hline
\end{tabular}

Due to the expected effects of daily temperature, relative humidity and precipitation on the estimated traits, weather data were obtained from the nearest weather station (20 kilometers) to the experimental site. A split-plot design, with four replicates, was used. The three water regime treatments were assigned to the main-plots, whereas, the sixteen genotypes were allocated in the sub - plots. The sub - plot area was 30 $\mathrm{m}^{2}$ (6 rows, $25 \mathrm{~m}$ long and $20 \mathrm{~cm}$ apart). Wheat grains of genotypes were sown in November $24^{\text {th }}$, in $2003 / 2004$ season, and December $2^{\text {nd }}$ in 2004/2005 season. Wide borders were kept among the main plots of different irrigation treatments to minimize surface and underground water permeability. All other culture practices, except for irrigation, were applied as recommended for the experimentation site. The following characters were measured in both seasons on a sub-plot basis: 
Table 2. The pedigree and origin of the sixteen bread wheat genotypes

\begin{tabular}{|c|c|c|c|}
\hline Serial No. & Genotypes & Pedigree & Origin \\
\hline 1 & Giza 155 & Regent / 2* Giza $139 / /$ Mida Cadet / 2* Hindi 162 & Egypt \\
\hline 2 & Sakha 61 & Inia / RL 4220 // 7C / Yr 'S' & Egypt \\
\hline 3 & Sakha 69 & Inia / RL 4220 // 7C / Yr 'S' & Egypt \\
\hline 4 & Sids 1 & HD 2172 / pavon 'S’ // 1158.57 / Maya 74 'S' & Egypt \\
\hline 5 & Sids 7 & Maya "S" / Mon "S" / CMH 74. A592 /3/ Sakha 8*2 & Egypt \\
\hline 6 & Gemmiza 7 & CMH 74 A. $630 / 5 x / /$ Seri 82 / 3 / Agent & Egypt \\
\hline 7 & Gemmiza 9 & Ald 'S' / Huac 'S' // CMH 74A. 630 / 5x & Egypt \\
\hline 8 & Giza 168 & MIL / BUC // Seri & Egypt \\
\hline 9 & Sakha 93 & Sakha 92/ TR 810328 & Egypt \\
\hline 10 & Line 1 & Giza 157 // SX / Cardinal & Egypt \\
\hline 11 & Line 2 & CHAM-4 // NS 732 / HER & Mexico \\
\hline 12 & Line 3 & MOUKA-4 & Mexico \\
\hline 13 & Line 4 & HE $1 / 3 *$ CNO79 // 2* SERI /3/ BORL 95 / 4/ YACO & Mexico \\
\hline 14 & Line 5 & CHOIX / STAR /3/ HE1/ 3* CNO $79 / / 2 *$ SERI & Mexico \\
\hline 15 & Line 6 & CROC-1 / AE. SQUARROSA (205) // KAUZ /3/ SASIA & Mexico \\
\hline 16 & Line 7 & HUD-2 & Mexico \\
\hline
\end{tabular}

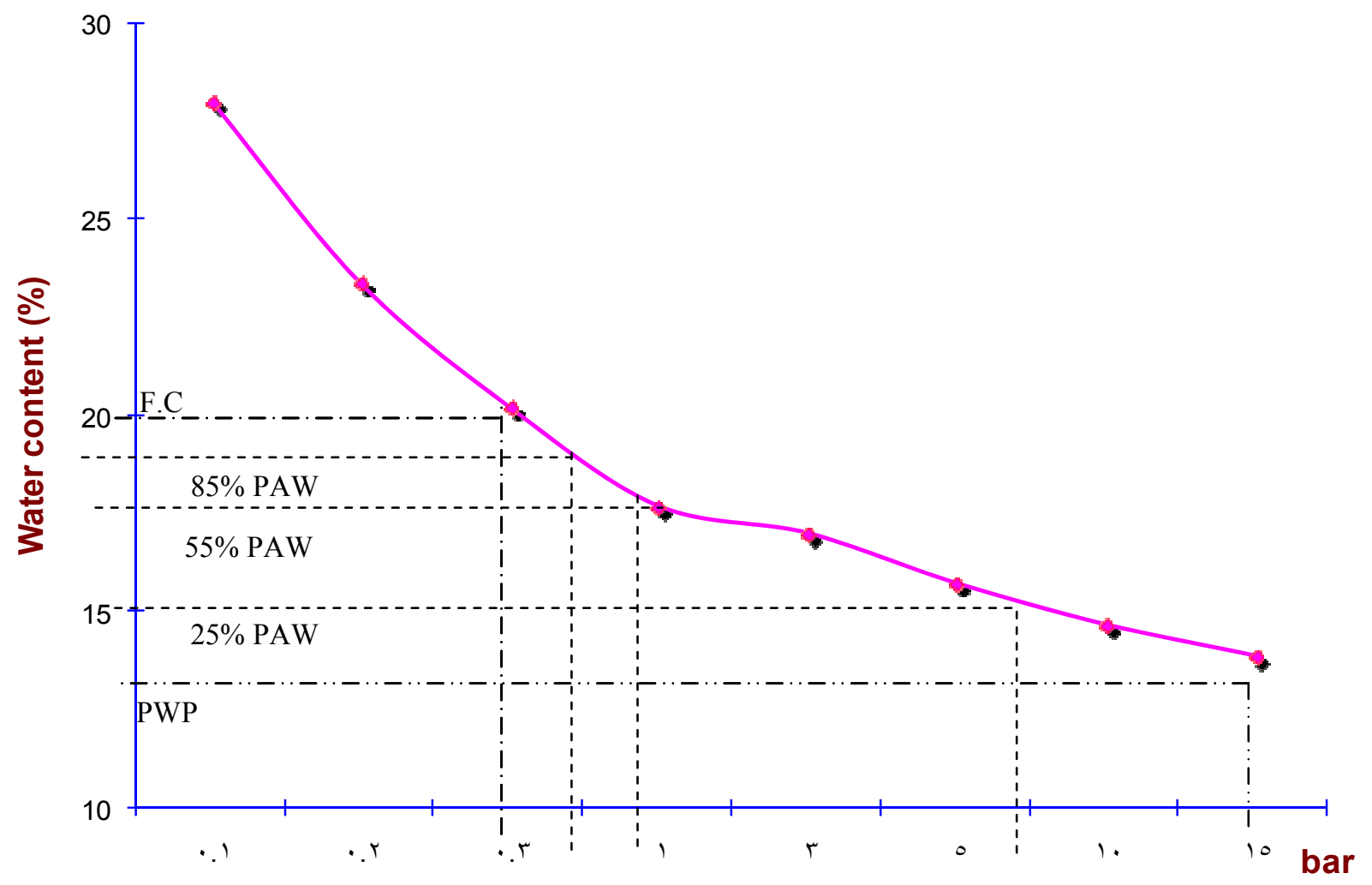

Fig. 1. Soil moisture characteristic curve of the experimental site at AL- Boustan Farm FC $=$ Field capacity $\quad$ PWP $=$ Permanent wilting point 


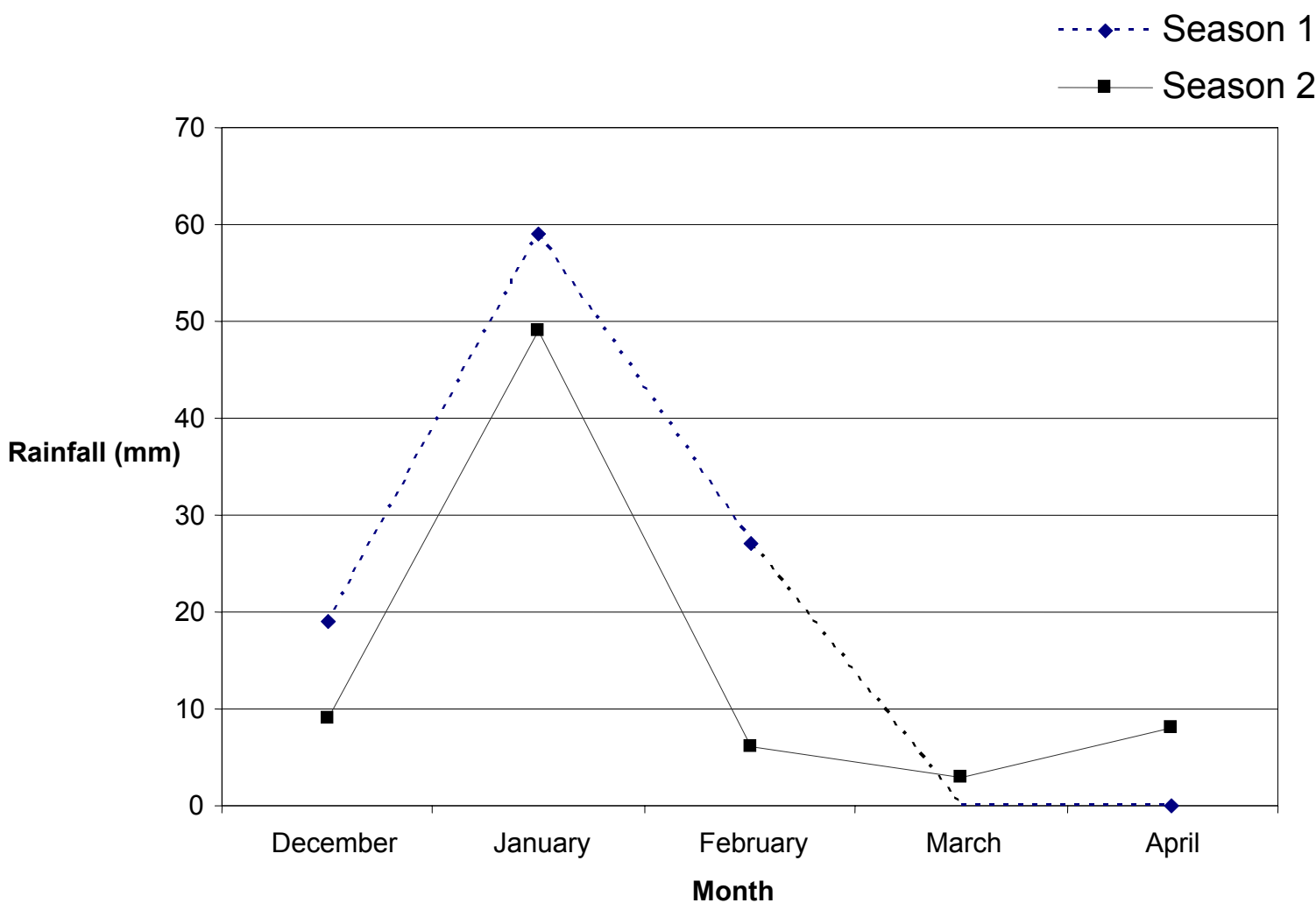

Fig. 2. Mean precipitation during the growth period of the two wheat growing seasons $(2003 / 2004$ and 2004/2005)

\section{1- Canopy temperature (Tc):}

It was measured for all tested genotypes with an infrared thermometer (Hertford Shire SG1 2TAEngland- A Vida Group Company) with a narrow field of view (3 deg), detecting radiation in the 8 to 14 micron wave bands. Canopy temperature measurements were scored at the booting stage of wheat development, where, the canopy cover was fully developed, covering soil surface. An average of ten instantaneous readings were scored from each sub-plot in a diagonal direction. Care had been taken to avoid interference with the exposed ground surface.

\section{2- Excised leaf water loss (ELWL):}

Leaves were sampled, starting at the booting stage of wheat development, for both seasons. Samples were collected between 8 and 9 hrs in the morning. Flag leaf and the following leaves were randomly collected from four plants for each sub- plot. The leaves were placed in plastic bags and transported to the laboratory as quickly as possible (within one hour). Fresh weight was determined and the leaves were placed in a controlled environment room at $25{ }^{\circ} \mathrm{C}$ and $50 \%$ relative humidity. The leaves were reweighed after 12 hours. Excised leaf water loss (\%) was calculated as follows:
ELWL $\frac{\text { Fresh weight }- \text { weight after } 12 \text { hours }}{\text { Fresh weight }} \times 100$

3- Number of days to heading: It was estimated as the number of days from sowing to 50 percent heading on each sub-plot basis.

4- Number of days to maturity: It was recorded as the number of days from sowing to the date of physiological yellow stage of maturity. The complete loss of green color from all spike parts was considered as an available indicator of physiological maturity (Donnelly, 1983).

5- Grain yield (ton/ha): Grain yield per one guarded random meter square was estimated as the weight of clean grains of each sub - plot and expressed as ton/ha.

6- Kernel weight (mg): It was recorded as the average of two random samples with 100 kernels of clean grain from each sub- plot at harvest and was expressed as mg / kernel.

7- Drought susceptibility index: It was calculated in both seasons on both grain yield (Sy) and kernel weight (Sk) indices. Grain yield susceptibility index (Sy) was used to characterize relative stress -loss in grain yield 
for all genotypes according to Fisher and Maurer (1978) as follows:

$$
\mathrm{Sy}=(1-\mathrm{Yr} / \mathrm{Yi}) /(1-\mathrm{Ymr} / \mathrm{Ymi})
$$

Where, $\mathrm{Yr}$ is stressed and $\mathrm{Yi}$ is non-stressed genotype yield means, and $\mathrm{Ymr}$ is stressed and $\mathrm{Ymi}$ is non- stressed environment yield means.

Regarding kernel weight susceptibility index (Sk), it was estimated as follows:

$\mathrm{Sk}=(1-\mathrm{Kr} / \mathrm{Ki}) /(1-\mathrm{Kmr} / \mathrm{Kmi})$

Where, $\mathrm{Kr}$ is stressed and $\mathrm{Ki}$ is non-stressed genotype kernel weight means, and $\mathrm{Kmr}$ is non-stressed environment kernel weight means.

Simple correlation coefficients between Sy and Sk with Tc and ELWL, in the most stress soil moisture level of $25 \% \mathrm{AW}$, were calculated in both seasons.

Data were statistically analyzed following the analysis of variance procedures, according to Gomez and Gomez (1984), using SAS computer system (SAS, 1985). Comparison of means was done, using the least significant difference test (LSD) at 5\%level of probability.

\section{RESULTS AND DISCUSSION}

\section{1-Canopy temperature (Tc):}

As shown in Table (3), Tc was highly significantly affected by soil moisture in both seasons. Tc was significantly increased by decreasing soil moisture, where, its increased from $17.00{ }^{\circ} \mathrm{C}$ in the most abundant soil moisture of $85 \% \mathrm{AW}$, to $18.95{ }^{\circ} \mathrm{C}$, in $55 \% \mathrm{AW}$, to $20.55{ }^{\circ} \mathrm{C}$ in the most stress soil moisture level of $25 \%$ AW, over both seasons (Tables 4 and 5). Figure (3) shows that the mean daily temperature, during the flowering period of the second growing season, was generally, warmer than that of the first growing season. However, the average of Tc, in the second season, was lower, comparing to the first season. This could be due to the differences in the daily ambient temperature, differences in time of measuring Tc and the different interaction in the evapotranspiration behavior of the studied genotypes with the ambient temperature.

Furthermore, highly significant differences in Tc, among genotypes were observed in both seasons, as shown in Table (3). In the first season, the introduced line 7 had the warmest Tc $\left(21.4{ }^{\circ} \mathrm{C}\right)$, while, Sids 1 had the coolest $\mathrm{Tc}\left(19.2^{\circ} \mathrm{C}\right)$. In the second season, Sids 7 had the warmest Tc $\left(18.7^{\circ} \mathrm{C}\right)$, while, Giza 168 had the coolest Tc $\left(16.7{ }^{\circ} \mathrm{C}\right)$, as shown in Tables (4 and 5). However, the ranks of different genotypes, according to their Tc values, were not widely different in both seasons. A highly significant rank correlation of (0.97) was obtained between the Tc rank values in both seasons under the most stress soil moisture level. The
Tc differences, among the genotypes, could be explained by

their different ability to keep absorbing soil moisture and to keep high rate of evapotranspiration under drought stress (Singh et al.,1985). In this case of plant behavior, Tc could be lowered for drought tolerant genotypes. However, other drought tolerant genotypes could have the ability to keep low rate of evapotranspiration under stress. Therefore, these plants could have a high Tc, comparing to other high water consuming plants (Saadalla and Alderfasi, 2000). The warmer Tc indicates stomatal closure and, hence, less water consumption during vegetative growth with the result that more available soil water is saved for the later reproductive stages. The obtained results were in agreement with the results of Losavio et al (1984), Choudhury and Idso ( 1985) and Siddique et al(2000).

The analysis of variance, in Table (3), showed highly significant effects of soil moisture by genotypes interaction on $\mathrm{Tc}$ in both seasons. It was clear, in $2003 / 2004$ season, that the local cultivar, Sids 7, had the warmest Tc $\left(23.7^{\circ} \mathrm{C}\right)$ at $25 \% \mathrm{AW}$, while, Sids 1 had the coolest Tc $\left(16.3{ }^{\circ} \mathrm{C}\right)$ at $85 \%$ AW. However, in $2004 / 2005$ season, Sids 7 cultivar had the warmest Tc $\left(19.4{ }^{\circ} \mathrm{C}\right.$ ) at $25 \% \mathrm{AW}$, while, Giza 168 cultivar had the coolest Tc $\left(15.6{ }^{\circ} \mathrm{C}\right)$ at $85 \%$ AW (Tables 4 and 5). Comparing the results of the two seasons, ranking of the most tolerant genotypes, as well as the most sensitive ones, had not widely changed (Tables 4 and 5).

\section{2- Excised leaf water loss (ELWL):}

Soil moisture highly significantly affected ELWL in both seasons (Table 3 ). It is obvious from the results, presented in Tables (6 and 7), that ELWL was significantly decreased from $51.40 \%$, in the most abundant soil moisture of $85 \%$ AW, to $45.7 \%$, in $55 \%$ $\mathrm{AW}$, to $41.10 \%$ in the most stressed soil moisture level of $25 \% \mathrm{AW}$, averaged in both seasons. Rate of water loss from excised wheat leaves was reported to be associated with plant adaptation to dry growing conditions (Dawood et al., 1988). Therefore, the most drought -tolerant genotype would have less rate of ELWL under the most stress drought conditions (Wang, 1993).

Concerning the effect of wheat genotypes on ELWL, the analysis of variance in Table(3) showed highly significant differences in both seasons. Sakha 61 local cultivar recorded the minimum ELWL value (42.6\% of its fresh weight) in the first season. On the other hand, the introduced Line 6 recorded the maximum ELWL value (57.8\% of its fresh weight) all over soil moisture levels (Table 6). In 2004/2005 season, the introduced line 4 recorded the minimum loss 


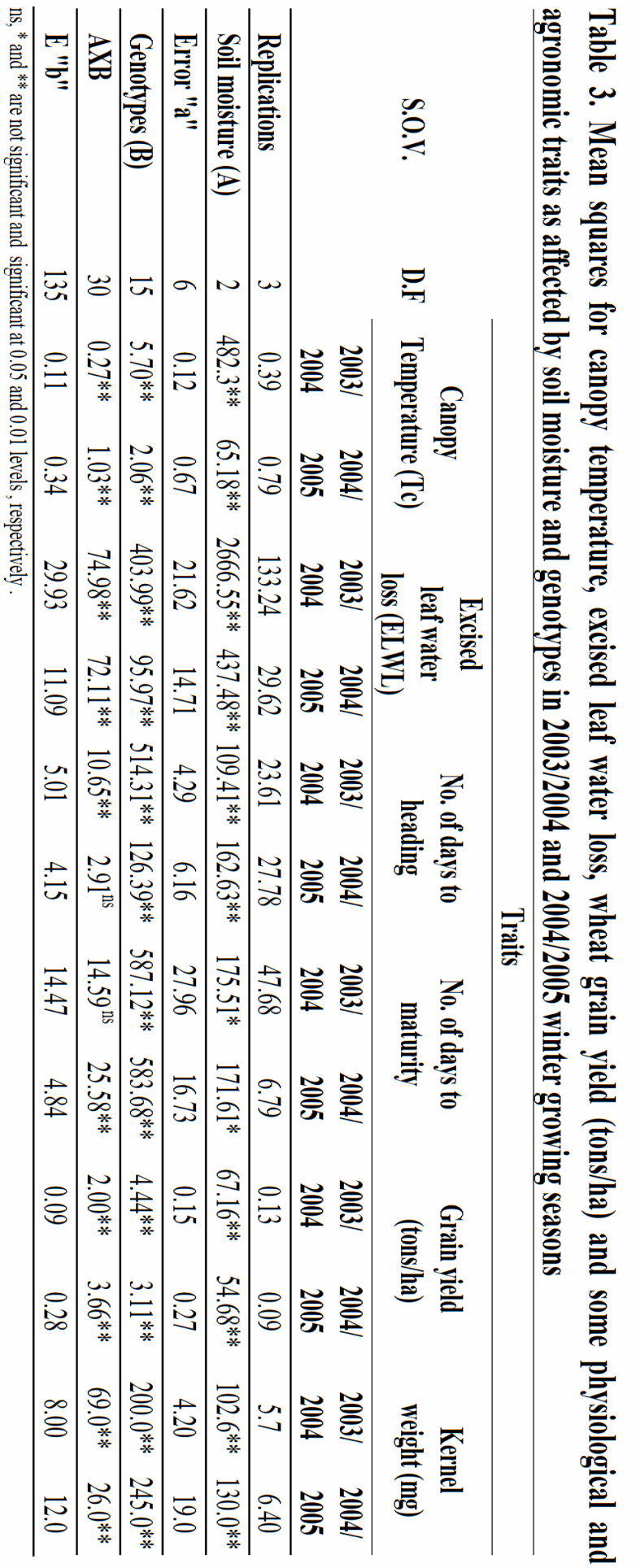




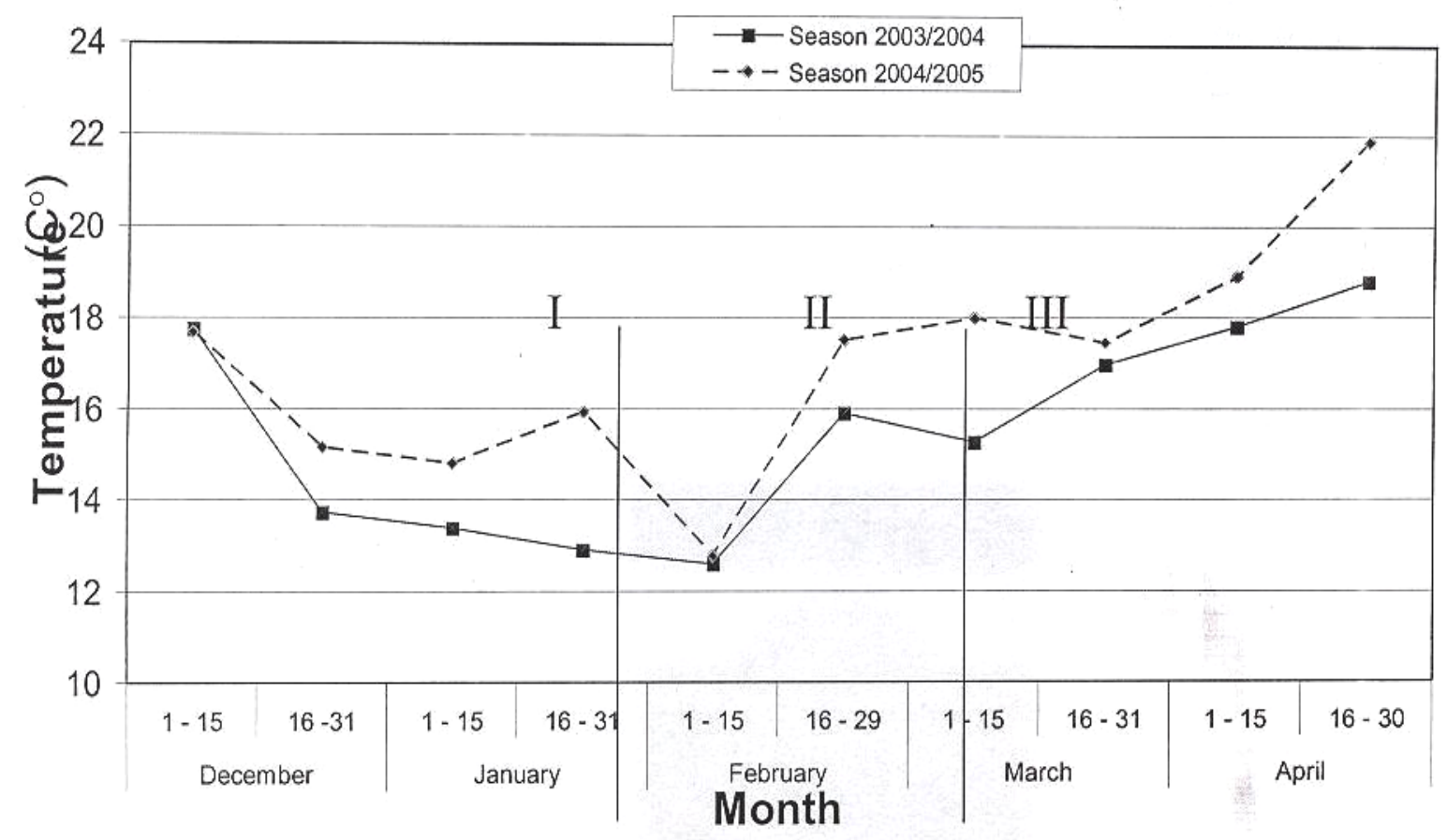

Fig 3. Mean daily temperature during the growing season of wheat at AL- Boustan in 2003/2004 and 2004/2005

\section{I- Vegetative stage. II- Reproductive stage. III- Ripening stage}

Table 4. Genotypic mean values of canopy temperature $\left({ }^{\circ} \mathrm{C}\right)$ as affected by soil moisture, genotypes and genotype $x$ soil moisture interaction in 2003/2004 season

\begin{tabular}{|c|c|c|c|c|c|c|c|c|}
\hline \multirow[b]{2}{*}{ Genotypes } & \multicolumn{2}{|c|}{$85 \%(A W)$} & \multicolumn{2}{|c|}{$55 \%(A W)$} & \multicolumn{2}{|c|}{$25 \%(A W)$} & \multicolumn{2}{|c|}{ Means $^{(1)}$} \\
\hline & & Rank & & Rank & & Rank & & Rank \\
\hline 1- Sids 1 & 16.3 & 13 & 19.3 & 10 & 21.9 & 9 & $19.2 \mathrm{~h}$ & 12 \\
\hline 2- Line 1 & 17.1 & 7 & 20.2 & 7 & 22.3 & 8 & $19.9 \mathrm{ef}$ & 8 \\
\hline 3- Sakha 93 & 17.2 & 6 & 20.6 & 5 & 22.7 & 6 & $20.2 \mathrm{~cd}$ & 5 \\
\hline 4- Giza 168 & 17.1 & 7 & 20.7 & 4 & 21.0 & 12 & $19.6 \mathrm{c}$ & 9 \\
\hline 5- Sakha 69 & 16.7 & 10 & 19.6 & 9 & 21.9 & 9 & $19.4 \mathrm{gh}$ & 11 \\
\hline 6- Giza 155 & 17.2 & 6 & 20.6 & 5 & 23.4 & 3 & $20.4 \mathrm{c}$ & 3 \\
\hline 7- Gemmiza 7 & 18.2 & 4 & 21.3 & 3 & 21.5 & 11 & $20.3 \mathrm{~b}$ & 4 \\
\hline 8- Sakha 61 & 17.0 & 8 & 20.4 & 6 & 21.6 & 10 & $19.7 \mathrm{de}$ & 8 \\
\hline 9- Gemmiza 9 & 18.3 & 3 & 21.3 & 3 & 22.6 & 7 & $20.7 \mathrm{~b}$ & 2 \\
\hline 10- Sids 7 & 16.6 & 11 & 19.6 & 9 & 23.7 & 1 & $19.9 \mathrm{~g}$ & 6 \\
\hline 11- Line 6 & 17.1 & 7 & 20.4 & 6 & 20.9 & 13 & $19.5 \mathrm{~cd}$ & 10 \\
\hline 12- Line 2 & 18.4 & 2 & 21.4 & 2 & 22.3 & 8 & $20.7 \mathrm{ab}$ & 2 \\
\hline 13- Line 7 & 18.8 & 1 & 21.9 & 1 & 23.5 & 2 & $21.4 \mathrm{a}$ & 1 \\
\hline 14- Line 3 & 16.8 & 9 & 19.9 & 8 & 22.7 & 6 & $19.8 \mathrm{fg}$ & 7 \\
\hline 15- Line 5 & 17.8 & 5 & 20.7 & 4 & 22.8 & 5 & $20.4 \mathrm{c}$ & 3 \\
\hline 16- Line 4 & 16.4 & 12 & 19.3 & 10 & 22.9 & 4 & $19.5 \mathrm{~h}$ & 10 \\
\hline Means ${ }^{(1)}$ & $17.3 \mathrm{a}$ & & $20.4 \mathrm{~b}$ & & $22.4 \mathrm{c}$ & & 20.0 & \\
\hline
\end{tabular}

(1) Means followed by the same letter (s) are not significantly different according to L.S.D. (0.05). 
Table 5. Genotypic mean values of canopy temperature $\left({ }^{\circ} \mathrm{C}\right)$ as affected by soil moisture, genotypes and genotype $x$ soil moisture interaction in 2004/ 2005 season

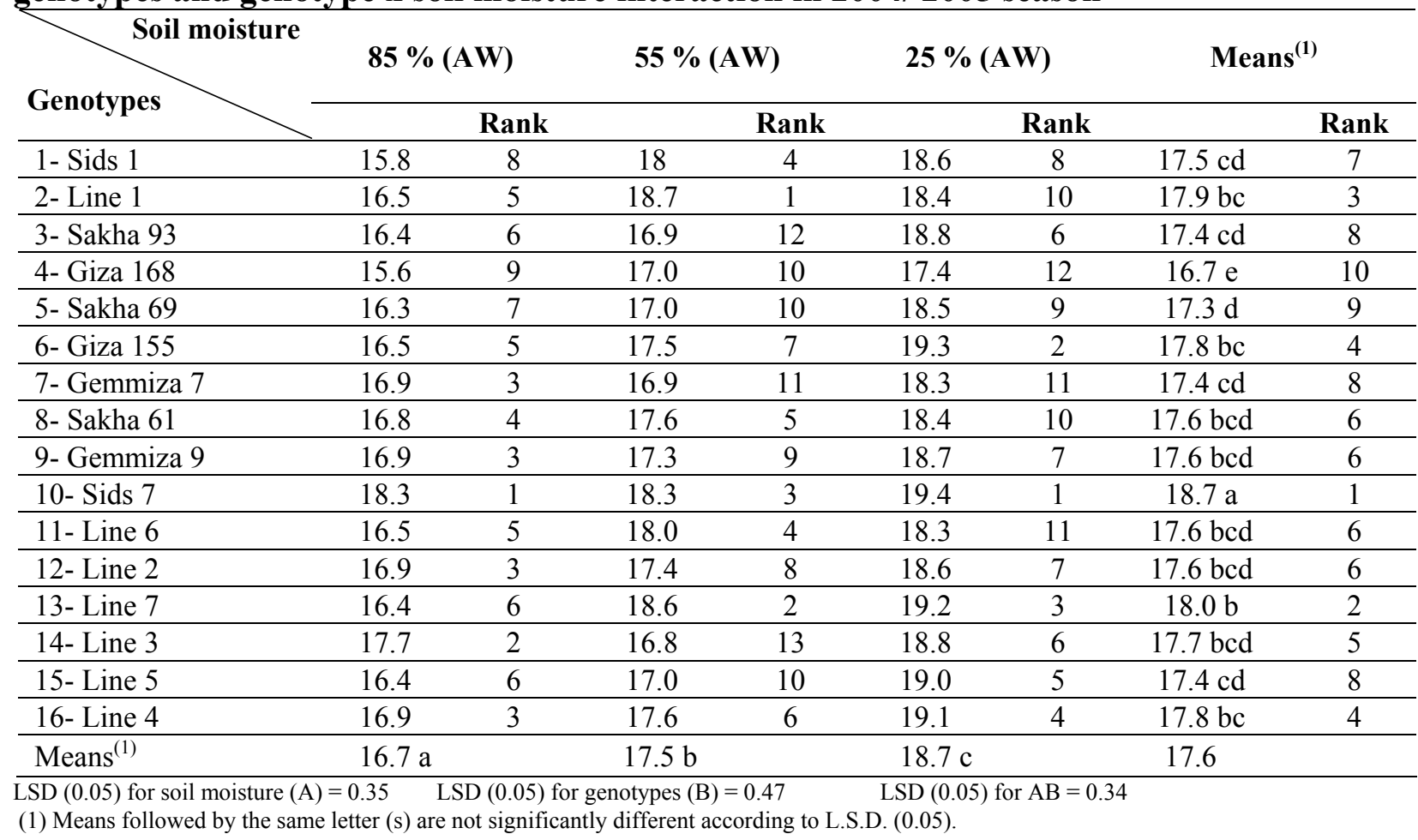

Table 6. Genotypic mean values of excised leaves water loss (ELWL) as affected by soil moisture, genotypes and genotype $x$ soil moisture interaction in 2003/2004 season

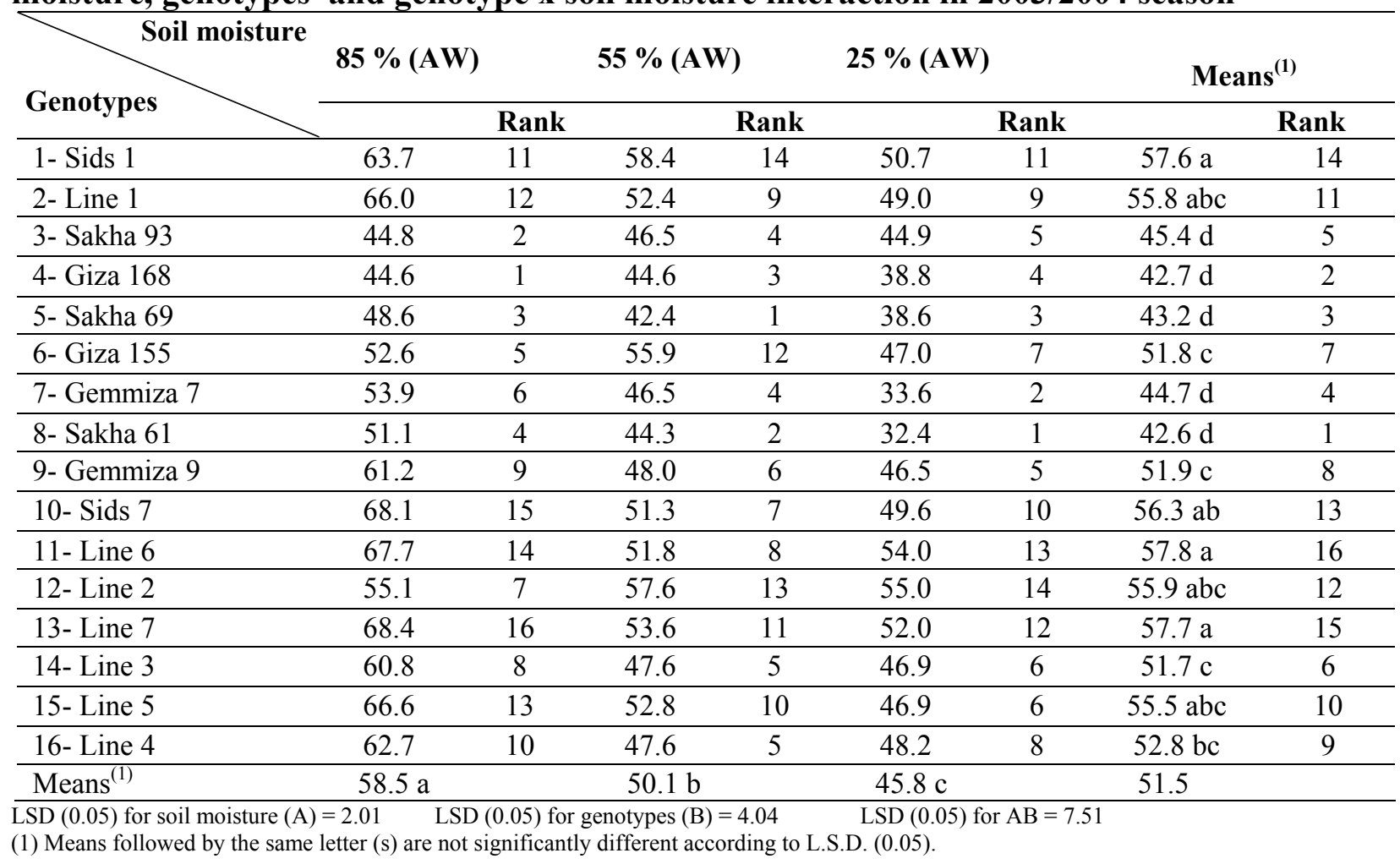


Table 7. Genotypic mean values of excised leaves water (ELWL) loss as affected by soil moisture, genotypes and genotype $x$ soil moisture interaction in 2004/2005 season

\begin{tabular}{|c|c|c|c|c|c|c|c|c|}
\hline \multirow{2}{*}{ Genotypes } & \multicolumn{2}{|c|}{$85 \%(A W)$} & \multicolumn{2}{|c|}{$55 \%(A W)$} & \multicolumn{2}{|c|}{$25 \%(A W)$} & \multicolumn{2}{|c|}{ Means $^{(1)}$} \\
\hline & & Rank & & Rank & & Rank & & Rank \\
\hline 1- Sids 1 & 40.7 & 4 & 39.3 & 3 & 41.0 & 12 & $40.3 \mathrm{~cd}$ & 8 \\
\hline 2- Line 1 & 41.0 & 5 & 34.5 & 2 & 39.0 & 10 & $38.2 \mathrm{de}$ & 2 \\
\hline 3- Sakha 93 & 52.5 & 16 & 40.6 & 7 & 35.0 & 4 & $42.7 \mathrm{ab}$ & 14 \\
\hline 4- Giza 168 & 47.0 & 12 & 45.1 & 14 & 35.7 & 6 & $42.6 \mathrm{a}$ & 13 \\
\hline 5- Sakha 69 & 42.0 & 7 & 47.3 & 16 & 33.8 & 3 & $41.0 \mathrm{ab}$ & 9 \\
\hline 6- Giza 155 & 51.0 & 14 & 42.5 & 8 & 37.0 & 9 & $43.5 \mathrm{a}$ & 16 \\
\hline 7- Gemmiza 7 & 44.6 & 10 & 42.6 & 9 & 32.9 & 2 & $40.0 \mathrm{cde}$ & 7 \\
\hline 8- Sakha 61 & 42.7 & 9 & 40.2 & 5 & 32.8 & 1 & $38.6 \mathrm{e}$ & 3 \\
\hline 9- Gemmiza 9 & 37.6 & 1 & 43.4 & 11 & 36.0 & 7 & $39.0 \mathrm{de}$ & 4 \\
\hline 10- Sids 7 & 51.2 & 15 & 43.6 & 12 & 35.5 & 5 & $43.4 \mathrm{ab}$ & 15 \\
\hline 11- Line 6 & 48.0 & 13 & 42.9 & 10 & 33.8 & 3 & $41.6 \mathrm{cde}$ & 10 \\
\hline 12- Line 2 & 41.5 & 6 & 45.4 & 15 & 40.0 & 12 & $42.3 \mathrm{bc}$ & 11 \\
\hline 13- Line 7 & 47.0 & 12 & 39.4 & 4 & 41.0 & 13 & $42.5 \mathrm{cde}$ & 12 \\
\hline 14- Line 3 & 39.0 & 2 & 40.4 & 6 & 39.5 & 11 & $39.6 \mathrm{de}$ & 6 \\
\hline 15- Line 5 & 40.6 & 3 & 44.2 & 13 & 33.8 & 3 & $39.5 \mathrm{de}$ & 5 \\
\hline 16- Line 4 & 42.3 & 8 & 28.9 & 1 & 36.1 & 8 & $35.8 \mathrm{f}$ & 1 \\
\hline Means $^{(1)}$ & $44.3 \mathrm{a}$ & & $41.3 \mathrm{~b}$ & & $36.4 \mathrm{c}$ & & 40.7 & \\
\hline
\end{tabular}

$\overline{\operatorname{LSD}}(0.05)$ for soil moisture $(\mathrm{A})=1.66 \quad \operatorname{LSD}(0.05)$ for genotypes $(\mathrm{B})=2.69 \quad \operatorname{LSD}(0.05)$ for $\mathrm{AB}=4.61$

(1) Means followed by the same letter (s) are not significantly different according to L.S.D. (0.05).

of ELWL (35.8\% of its fresh weight), while, Giza 155 local cultivar recorded the maximum ELWL value (43.5\%of its fresh weight), as shown from Table 7. Furthermore, the ranking of different genotypes for their ELWL, was not widely different from one season to another. A highly significant rank correlation of (0.63) was obtained between the ELWL rank values in both seasons under the most soil moisture levels. The present results are in agreement with those of John et al (1982), Clarke et al (1989), Balota (1995) and Farshadfar et al (2001).

The interaction effect, between soil moisture and genotypes, on ELWL was highly significant in both seasons (Table 3). In the first season, Sakha 61 was the most drought tolerant, where it recorded a loss of $32.4 \%$ of its fresh weight at the most stressed soil moisture level. On the other hand, the most drought non- tolerant genotype (Line 2) recorded the highest loss of its fresh weight $(55.0 \%)$ at the same level of soil moisture (the most stressed), as shown from Table (6). In the second season, the highest tolerant genotype to drought was Sakha 61, where it recorded less ELWL value (32.8\%) of its fresh weight at the lowest level of moisture (25\%). While, the most drought non-tolerant genotype was Sakha 93 , where it recorded a high loss of $52 \%$ of its fresh weight at the highest soil moisture level $(85 \%$ AW), as shown from Table (7).

\section{3- Number of days to heading:}

Data in Table (3) revealed that the number of days to heading was highly significantly affected by soil moisture, in both seasons. Heading date was significantly decreased from 94.92 days in the most abundant soil moisture of $85 \% \mathrm{AW}$, to 93.2 days in $55 \%$ AW and to 92.06 days in the most stress soil moisture level of $25 \% \mathrm{AW}$, as averages of both seasons (Tables 8 and 9). It was evident, from Table (3), that a highly significant effect was found among genotypes for heading date in the two seasons. In the first season, the earliest genotype in heading was Sakha 61, where it recorded 80.08 days, while, the latest genotype was Line 2, where it recorded 107.00 days (Table 8). In the second season the earliest genotype in heading was Sids 7 , where it recorded 87.25 days, while, the latest genotype was Line 4 where it recorded 97.92 days (Table 9).

The analysis of variance for the interaction between soil moisture and genotypes, as shown in Table 3 , had a highly significant effect on heading date in the first season, but, it had a non- significant effect in the second season. The earliest genotype in heading was Sakha 61, where it recorded 79.00 days in the lowest soil moisture level, while, the latest genotype in heading was Line 2, where it recorded 108 days in the highest soil moisture level (Table 8 ). The obtained results were in agreement with those of Ghandorah (1989). 


\section{4- Number of days to maturity:}

The data in Table (3) further indicated that the number of days to maturity was significantly affected by soil moisture in both seasons. Number of days to maturity was significantly decreased from 142.84 , days in the most abundant soil moisture of $85 \% \mathrm{AW}$, to 140.69 days in 55\% AW and to 139.60 days in the most stressed soil moisture level of $25 \% \mathrm{AW}$, over the two seasons (Table 9 and 10 ).

Highly significant differences among genotypes for number of days to maturity, in both seasons, were recorded (Table 3). Sakha 61 was the earliest genotype in both seasons, where it recorded 129.58 and 130.83 days in the first and second seasons, respectively. On the other hand, the latest genotype was Line 2 in the two seasons, where it recorded 154.67 and 154.0 days to maturity in the first and second seasons, respectively (Tables 9 and 10). Similar results were obtained by Desalegn et al (2001), where they detected differences in number of days to maturity among different genotypes.

As shown from Table (3), a non- significant effect of the interaction (soil moisture $\mathrm{x}$ genotypes) was observed on number of days to maturity, in the first season, but, there was a highly significant effect in the second season. The earliest genotype was Sakha 61, where it recorded 128 days in the second level of soil moisture. The latest genotype was Line 2, where it recorded 157

days in soil moisture in the first level of soil moisture for number of days to maturity in the second season (Table 10).

\section{5- Grain yield (GY):}

Analysis of variance in Table (3) showed a highly significant effect of soil moisture on GY in both seasons. Tables (11 and 12) indicated a significant increase in GY with increased soil moisture. Over the two seasons, GY was significantly decreased from 5.38 tons $/$ ha, in the most abundant soil moisture of $85 \%$ $\mathrm{AW}$, to 4.54 tons/ha in $55 \% \mathrm{AW}$ and to 3.84 tons/ ha in the most stressed soil moisture level of $25 \%$ AW. Such results are in agreement with those of Kheiralla et al, 1993; El-Nagar et al., 1997; Ahmed et al., 1998; Dragavtsev et al., 1999 and Desalegn et al., 2001.

Results, also, indicated highly significant differences among genotypes for GY all over soil moisture levels in both seasons, as shown in Table (3). The highest genotypes for GY were Sakha 69 and Line 7, where they recorded 4.94 and 5.69 tons/ha in the first and second seasons, respectively. On the other hand, the lowest genotypes were Line 2 and Giza 155, which yielded 3.27 and 4.03 tons/ ha for GY in the first and second seasons, respectively (Tables 11 and 12).

Table 8. Genotypic mean number of days to heading as affected by soil moisture, genotypes and genotype $x$ soil moisture interaction in $2003 / 2004$ season

\begin{tabular}{|c|c|c|c|c|}
\hline $\begin{array}{l}\text { Soil moisture } \\
\text { Genotypes }\end{array}$ & $85 \%(\mathrm{AW})$ & $55 \%(A W)$ & $25 \%(\mathrm{AW})$ & Means $^{(1)}$ \\
\hline 1 - Sids 1 & 95.00 & 94.75 & 92.50 & $94.08 \mathrm{e}$ \\
\hline 2- Line 1 & 100.0 & 96.25 & 95.25 & $97.17 \mathrm{~cd}$ \\
\hline 3- Sakh 93 & 88.25 & 83.00 & 83.00 & $84.75 \mathrm{i}$ \\
\hline 4- Giza 168 & 90.25 & 85.25 & 88.00 & $87.83 \mathrm{~h}$ \\
\hline 5- Sakha 69 & 87.75 & 89.75 & 86.25 & $87.92 \mathrm{~h}$ \\
\hline 6- Giza 155 & 92.25 & 89.00 & 88.25 & $89.83 \mathrm{~g}$ \\
\hline 7- Gemmiza 7 & 90.50 & 96.50 & 87.25 & $91.42 \mathrm{fg}$ \\
\hline 8- Sakha 61 & 80.75 & 80.50 & 79.00 & $80.08 \mathrm{j}$ \\
\hline 9- Gemmiza 9 & 99.00 & 99.25 & 97.00 & $98.42 \mathrm{bc}$ \\
\hline 10- Sids 7 & 99.50 & 98.75 & 96.25 & $98.17 \mathrm{bc}$ \\
\hline 11- Line 6 & 97.25 & 95.50 & 94.25 & $95.67 \mathrm{de}$ \\
\hline 12- Line 2 & 108.0 & 107.0 & 106.0 & $107.00 \mathrm{a}$ \\
\hline 13- Line 7 & 96.25 & 96.50 & 94.00 & $92.25 \mathrm{f}$ \\
\hline 14- Line 3 & 98.25 & 97.75 & 97.50 & $97.83 \mathrm{bc}$ \\
\hline 15- Line 5 & 96.00 & 93.00 & 95.25 & $94.75 \mathrm{e}$ \\
\hline 16- Line 4 & 100.75 & 99.50 & 98.25 & $99.50 \mathrm{~b}$ \\
\hline Means $^{(1)}$ & $94.98 \mathrm{a}$ & $93.83 \mathrm{~b}$ & $92.38 \mathrm{c}$ & 93.73 \\
\hline
\end{tabular}

LSD (0.05) for soil moisture (A) $=0.89 \quad \operatorname{LSD}(0.05)$ for genotypes $(\mathrm{B})=1.81 \quad \operatorname{LSD}(0.05)$ for $\mathrm{AB}=3.08$

(1) Means followed by the same letter (s) are not significantly different according to L.S.D. (0.05). 
Table 9. Genotypic mean number of days to heading and days to maturity as affected by soil mositure and genotypes in $2003 / 2004$ and $2004 / 2005$ seasons

\begin{tabular}{|c|c|c|}
\hline Treatments & $\begin{array}{l}\text { No. of days to heading } \\
(2004 / 2005)\end{array}$ & $\begin{array}{c}\text { No. of days to maturity } \\
(2003 / 2004)\end{array}$ \\
\hline \multicolumn{3}{|l|}{ Soil moisture } \\
\hline $85 \%(\mathrm{AW})$ & $94.86 \mathrm{a}$ & $142.97 \mathrm{a}$ \\
\hline $55 \%(\mathrm{AW})$ & $92.57 \mathrm{~b}$ & $140.73 \mathrm{ab}$ \\
\hline $25 \%(\mathrm{AW})$ & $91.73 \mathrm{~b}$ & $139.73 \mathrm{~b}$ \\
\hline \multicolumn{3}{|l|}{ Genotypes } \\
\hline 1-Sids 1 & $93.33 \mathrm{de}$ & $141.83 \mathrm{c}$ \\
\hline 2-Line 1 & $96.42 \mathrm{ab}$ & $146.25 \mathrm{~b}$ \\
\hline 3-Sakha 93 & $88.17 \mathrm{~g}$ & $137.17 \mathrm{e}$ \\
\hline 4-Giza 168 & $93.50 \mathrm{de}$ & $132.25 \mathrm{fg}$ \\
\hline 5-Sakha 69 & $90.92 \mathrm{f}$ & $138.42 \mathrm{de}$ \\
\hline 6-Giza 155 & $92.50 \mathrm{ef}$ & $133.08 \mathrm{f}$ \\
\hline 7-Gemmiza 7 & $93.33 \mathrm{de}$ & $139.00 \mathrm{cde}$ \\
\hline 8-Sakha 61 & $87.33 \mathrm{~g}$ & $129.58 \mathrm{~g}$ \\
\hline 9-Gemmiza 9 & $97.17 \mathrm{a}$ & $147.00 \mathrm{~b}$ \\
\hline 10-Sids 7 & $87.25 \mathrm{~g}$ & $145.83 \mathrm{~b}$ \\
\hline 11-Line 6 & $95.42 \mathrm{bc}$ & $132.67 \mathrm{f}$ \\
\hline 12-Line 2 & $94.50 \mathrm{~cd}$ & $154.67 \mathrm{a}$ \\
\hline 13-Line 7 & 93.92 cde & $141.00 \mathrm{~cd}$ \\
\hline 14-Line 3 & $94.33 \mathrm{~cd}$ & $146.50 \mathrm{~b}$ \\
\hline 15-Line 5 & $93.83 \mathrm{cde}$ & $145.17 \mathrm{~b}$ \\
\hline 16-Line 4 & $97.92 \mathrm{a}$ & $147.92 \mathrm{~b}$ \\
\hline
\end{tabular}

Table 10.Genotypic mean number of days to maturity as affected by soil moisture, genotypes and genotype $x$ soil moisture interaction in $2004 / 2005$ season

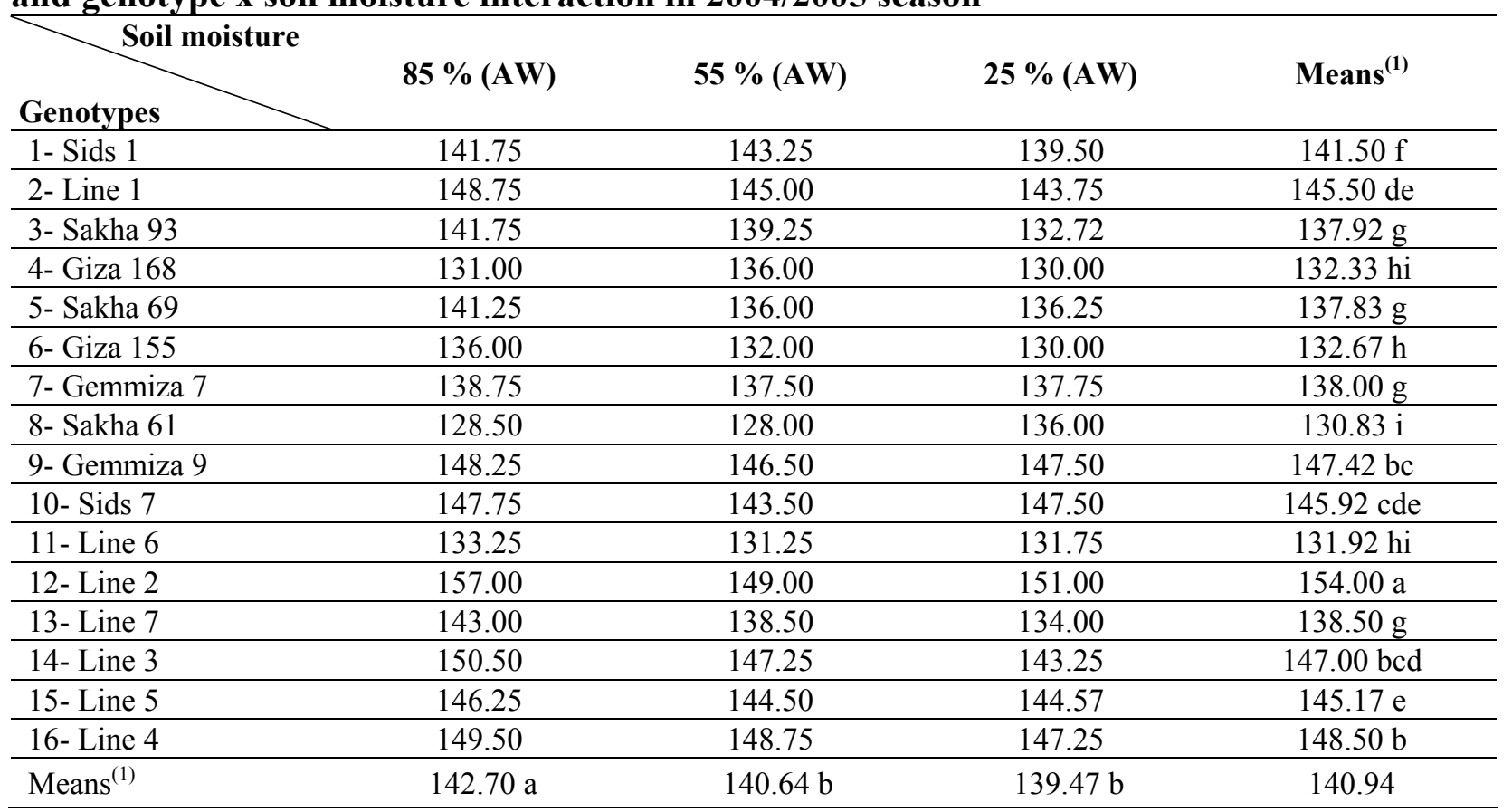

LSD (0.05) for soil moisture (A) = 1.77 $\quad$ LSD (0.05) for genotypes (B) $=1.87 \quad \operatorname{LSD}(0.05)$ for AB $=3.15$

(1) Means followed by the same letter (s) are not significantly different according to L.S.D. (0.05). 
Furthermore highly significant soil moisture $\mathrm{X}$ genotypes interaction was revealed for GY in both seasons (Table 3). Variable GY was recorded for the sixteen genotypes at the different soil moisture levels. Under $85 \%$ AW, Sakha 69 was the highest yielding (5.99 tons/ha), while, Line 2 was the lowest yielding ( 3.9 tons/ha) at the same level of soil moisture in the first season. Furthermore, under 25\% AW, Sakha 69 was still the highest yielding (4.30 tons/ha), while, Giza 155 was the lowest yielding (2.59 tons/ha), as shown in Table (11). In the second season, Line 7 was the highest yielding (6.88 tons/ha) under $85 \% \mathrm{AW}$, while, Gemmiza 7 was the lowest yielding (4.63 tons/ha) under the same level of soil moisture. However, Line 1 was the highest yielding (4.57 tons/ha) under $25 \% \mathrm{AW}$, while, Giza 155 was the lowest yielding (3.25 tons/ha) under the same level of soil moisture (Table 12). Similar genotypic differences, in grain yield, were obtained by Ghandorah (1989).

\section{6-Grain yield susceptibility index (SY):}

Values of Sy indicated significant differences for Sy among entries within years with consistently higher grain yields under high available water, comparing to low available water environments. The susceptibility index based on grain yield (Sy), for the two seasons, are reported in Table 13, where, drought tolerant entries, with low relative reduction in grain yield, had Sy values lower than one in the referred environments.

A season -to - season comparison of the genotypic Sy values indicated some consistency, where most of the

Table 11. Genotypic mean values of grain yield (tons/ha)as affected by soil moisture, genotypes and genotype $x$ soil moisture interaction in 2003/2004 season

\begin{tabular}{|c|c|c|c|c|}
\hline $\begin{array}{l}\text { Soil moisture } \\
\text { Genotypes }\end{array}$ & $85 \%(A W)$ & $55 \%(\mathrm{AW})$ & $25 \%(\mathrm{AW})$ & Means $^{(1)}$ \\
\hline 1 - Sids 1 & 5.17 & 4.15 & 3.80 & $4.37 \mathrm{~cd}$ \\
\hline 2- Line 1 & 4.97 & 3.45 & 3.00 & $3.80 \mathrm{e}$ \\
\hline 3- Sakha 93 & 5.41 & 4.30 & 3.20 & $4.30 \mathrm{~cd}$ \\
\hline 4- Giza 168 & 5.57 & 4.05 & 3.04 & $4.22 \mathrm{~d}$ \\
\hline 5- Sakha 69 & 5.99 & 4.54 & 4.30 & $4.94 \mathrm{a}$ \\
\hline 6- Giza 155 & 4.50 & 3.98 & 2.59 & $3.69 \mathrm{e}$ \\
\hline 7- Gemmiza 7 & 5.25 & 3.98 & 3.88 & $4.37 \mathrm{~cd}$ \\
\hline 8- Sakha 61 & 4.39 & 3.69 & 2.89 & $3.66 \mathrm{e}$ \\
\hline 9- Gemmiza 9 & 5.12 & 4.96 & 3.98 & $4.69 \mathrm{ab}$ \\
\hline 10- Sids 7 & 4.76 & 4.60 & 3.44 & $4.27 \mathrm{~cd}$ \\
\hline 11- Line 6 & 5.21 & 5.15 & 3.97 & $4.78 \mathrm{a}$ \\
\hline 12- Line 2 & 3.90 & 3.00 & 2.92 & $3.27 \mathrm{f}$ \\
\hline 13- Line 7 & 4.19 & 3.88 & 3.00 & $3.69 \mathrm{e}$ \\
\hline 14- Line 3 & 5.23 & 4.24 & 4.00 & $4.49 \mathrm{bc}$ \\
\hline 15- Line 5 & 5.33 & 4.60 & 4.23 & $4.72 \mathrm{ab}$ \\
\hline 16- Line 4 & 4.16 & 3.92 & 3.54 & $3.87 \mathrm{e}$ \\
\hline Means $^{(1)}$ & $4.94 \mathrm{a}$ & $4.16 \mathrm{~b}$ & $3.49 \mathrm{c}$ & 4.19 \\
\hline
\end{tabular}

LSD (0.05) for soil moisture (A) $=0.17 \quad \operatorname{LSD}(0.05)$ for genotypes $(\mathrm{B})=0.25$

(1) Means followed by the same letter (s) are not significantly different according to L.S.D. (0.05). genotypes consistently tended to have Sy on value lower or higher than one (Table 13). There was a negative correlation (not significant) between Tc and Sy values in the two seasons (Table 14). This could be explained by the high ability of the high yielding cultivars to keep a high rate of evapotranspiration and, consequently, low CT under such stress condition (McCaig and Romagosa, 1989). There was a significant positive correlation in the second season between Sy and ELWL, while, there was a non - significant negative correlation in the first season (Table 14). These results could be ascribed to a higher level of precipitation in the first season, compared to the second one (Fig. 2).

\section{7- Kernel weight (mg):}

Results indicated a significant increase in kernel weight with increased soil moisture. Kernel weight was significantly decreased from $53.65 \mathrm{mg}$, in the most abundant soil moisture of $85 \% \mathrm{AW}$, to $50.5 \mathrm{mg}$ in $55 \%$ AW and to 46.2 in the most stressed soil moisture level of $25 \% \mathrm{AW}$, averaged in both seasons (Tables 15 and 16). These results were supported by the results reported by Shalaby et al (1992). Data in Table 3, also, showed that highly significant differences were detected among genotypes kernel weight in both seasons. In the first soil moisture levels, was Gemmiza 7(55.6 mg), while, the lowest genotype was Line $7(43.3 \mathrm{mg})$, as shown from Table(15). In the second season, the highest genotype was Sakha 61 (59.3 mg), while, the lowest genotype was Line $7(44.7 \mathrm{mg})$, as shown from Table (16). season, the highest genotype for kernel weight, all over 
Table 12. Genotypic mean values of grain yield (tons/ha) as affected by soil moisture, genotypes and genotype $x$ soil moisture interaction in $2004 / 2005$ season

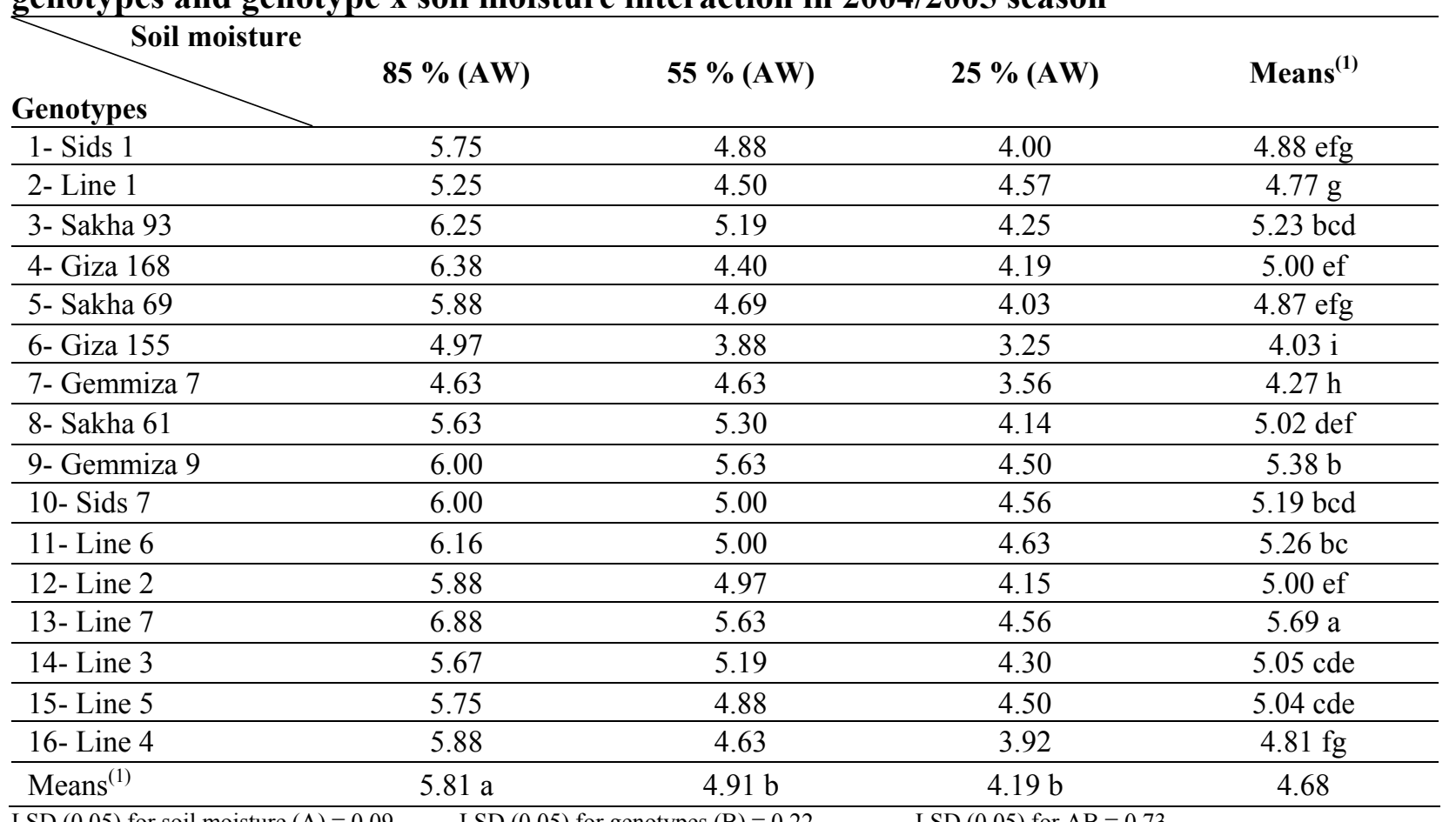

LSD (0.05) for soil moisture (A) $=0.09 \quad \operatorname{LSD}(0.05)$ for genotypes $(\mathrm{B})=0.22 \quad \operatorname{LSD}(0.05)$ for $\mathrm{AB}=0.73$

(1) Means followed by the same letter (s) are not significantly different according to L.S.D. (0.05).

Table 13. Drought susceptibility index calculated on grain yield basis (Sy)and kernel weight basis (Sk) of sixteen wheat genotypes exposed to two contrasting soil available water conditions

\begin{tabular}{lcccccccc}
\hline \multirow{2}{*}{ Genotypes } & \multicolumn{4}{c}{ Sy (GY) } & \multicolumn{4}{c}{ Sk (100-KW) } \\
\cline { 2 - 8 } & $\mathbf{2 0 0 3 / 2 0 0 4}$ & Rank & $\mathbf{2 0 0 4 / 2 0 0 5}$ & Rank & $\mathbf{2 0 0 3 / 2 0 0 4}$ & Rank & $\mathbf{2 0 0 4 / 2 0 0 5}$ & Rank \\
\hline 1- Sids 1 & 0.95 & 7 & 1.08 & 6 & 1.2 & 11 & 1.28 & 11 \\
\hline 2- Line 1 & 1.41 & 11 & 1.14 & 8 & 0.98 & 4 & 1.03 & 5 \\
\hline 3- Sakha 93 & 1.46 & 12 & 1.15 & 9 & 0.87 & 2 & 1.04 & 6 \\
\hline 4- Giza 168 & 1.5 & 14 & 1.23 & 11 & 1.03 & 6 & 0.96 & 1 \\
\hline 5- Sakha 69 & 1.01 & 9 & 1.12 & 7 & 0.7 & 1 & 1.00 & 3 \\
\hline 6- Giza 155 & 1.55 & 16 & 1.26 & 13 & 1.1 & 8 & 1.01 & 4 \\
\hline 7- Gemmiza 7 & 0.93 & 6 & 0.83 & 2 & 0.93 & 3 & 0.97 & 2 \\
\hline 8- Sakha 61 & 1.2 & 10 & 0.95 & 5 & 1.05 & 7 & 1.04 & 6 \\
\hline 9- Gemmiza 9 & 0.8 & 2 & 0.89 & 4 & 1.3 & 14 & 1.3 & 13 \\
\hline 10- Sids 7 & 0.99 & 8 & 0.86 & 3 & 1.15 & 10 & 1.25 & 10 \\
\hline 11- Line 6 & 0.85 & 4 & 0.89 & 4 & 0.99 & 5 & 1.26 & 12 \\
\hline 12- Line 2 & 0.89 & 5 & 0.95 & 5 & 1.29 & 13 & 1.25 & 10 \\
\hline 13- Line 7 & 1.47 & 13 & 1.24 & 12 & 0.99 & 5 & 1.28 & 11 \\
\hline 14- Line 3 & 0.84 & 3 & 0.86 & 3 & 1.12 & 9 & 1.2 & 9 \\
\hline 15- Line 5 & 0.73 & 1 & 0.77 & 1 & 1.2 & 11 & 1.19 & 8 \\
\hline 16- Line 4 & 1.53 & 15 & 1.19 & 10 & 1.24 & 12 & 1.18 & 7 \\
\hline
\end{tabular}


Table 14. Rank and rank correlation of grain yield susceptibility index (Sy) canopy temperature (Tc) and excised leaf water loss (ELWL)

\begin{tabular}{|c|c|c|c|c|c|c|c|c|}
\hline \multirow{2}{*}{ Genotypes } & \multicolumn{2}{|c|}{$2003 / 2004$} & \multicolumn{2}{|c|}{$2004 / 2005$} & \multicolumn{2}{|c|}{ 2003/2004 } & \multicolumn{2}{|c|}{ 2004/2005 } \\
\hline & Sy & Tc & Sy & Tc & Sy & ELWL & Sy & ELWL \\
\hline 1- Sids 1 & 7 & 9 & 6 & 8 & 7 & 11 & 6 & 12 \\
\hline 2- Line 1 & 11 & 8 & 8 & 10 & 11 & 9 & 8 & 10 \\
\hline 3- Sakha 93 & 12 & 6 & 9 & 6 & 12 & 5 & 9 & 4 \\
\hline 4- Giza 168 & 14 & 12 & 11 & 12 & 14 & 4 & 11 & 6 \\
\hline 5- Sakha 69 & 9 & 9 & 7 & 9 & 9 & 3 & 7 & 3 \\
\hline 6- Giza 155 & 16 & 3 & 13 & 1 & 16 & 7 & 13 & 9 \\
\hline 7- Gemmiza 7 & 6 & 11 & 2 & 11 & 6 & 2 & 2 & 2 \\
\hline 8- Sakha 61 & 10 & 10 & 5 & 10 & 10 & 1 & 5 & 1 \\
\hline 9- Gemmiza 9 & 2 & 7 & 4 & 7 & 2 & 5 & 4 & 7 \\
\hline 10 - Sids 7 & 8 & 1 & 3 & 2 & 8 & 10 & 3 & 5 \\
\hline 11- Line 6 & 4 & 13 & 4 & 11 & 4 & 13 & 4 & 3 \\
\hline 12- Line 2 & 5 & 8 & 5 & 7 & 5 & 14 & 5 & 12 \\
\hline 13- Line 7 & 13 & 2 & 12 & 3 & 13 & 12 & 12 & 13 \\
\hline 14- Line 3 & 3 & 6 & 3 & 6 & 3 & 6 & 3 & 11 \\
\hline 15- Line 5 & 1 & 5 & 1 & 5 & 1 & 6 & 1 & 3 \\
\hline 16- Line 4 & 15 & 4 & 10 & 4 & 15 & 8 & 10 & 8 \\
\hline Rank correlatior & & & & & & & & $9 *$ \\
\hline
\end{tabular}

- Significant at 0.05 level

Table 15.Genotypic mean kernel weight $(\mathrm{mg})$ as affected by soil moisture, genotypes and genotype $x$ soil moisture interaction in $2003 / 2004$ season

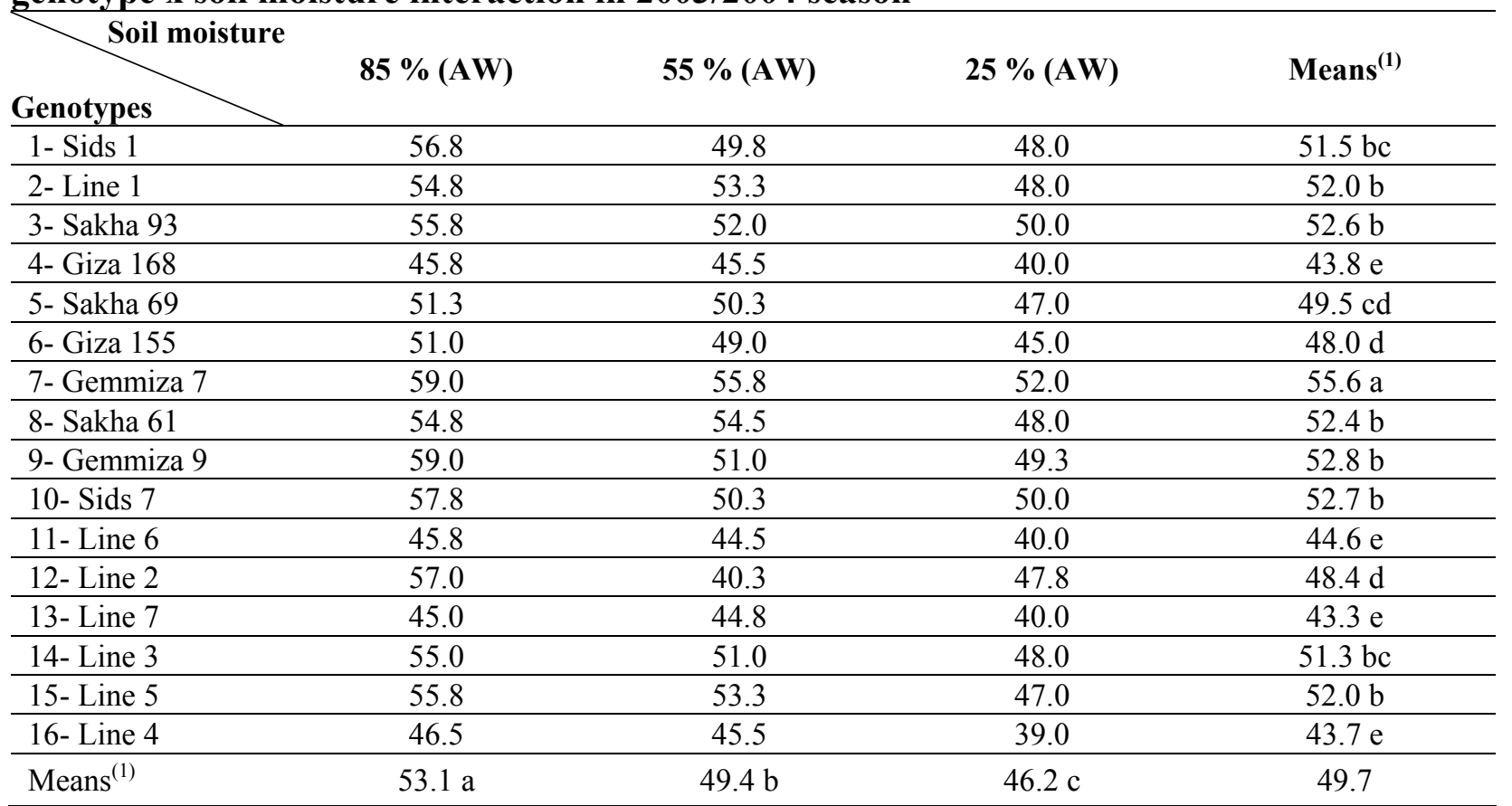

$\mathrm{LSD}(0.05)$ for soil moisture (A) $=0.9 \quad \operatorname{LSD}(0.05)$ for genotypes $(\mathrm{B})=2.3 \quad \operatorname{LSD}(0.05)$ for $\mathrm{AB}=3.9$

(1) Means followed by the same letter (s) are not significantly different according to L.S.D. (0.05). 
A highly significant soil moisture $\mathrm{X}$ genotypes interaction was revealed in both seasons (Table 3 ). Variable kernel weight was recorded for the studied sixteen genotypes at the different soil moisture levels. In 2003/ 2004 season, Gemmiza 7 was the heaviest genotype for kernel weight $(59.0 \mathrm{mg})$ at $85 \% \mathrm{AW}$, while, the lightest genotype was Line $4(39.0 \mathrm{mg})$ at $25 \%$ AW (Table 15). In 2004/2005 season, Sakha 61 was the highest genotype for this trait, where, it recorded ( $63.6 \mathrm{mg}$ ) at $85 \% \mathrm{AW}$, while, the lowest genotype was Line 7 , where it recorded $(40.0 \mathrm{mg})$ at $25 \%$ AW (Table 16). The obtained results were in agreement with those of EL-Nagar et al., 1997; Ahmed et al., 1998; Dencic et al., 2000 and Desalegen et al., 2001.

\section{8- Kernel weight susceptibility index (Sk):}

Data indicated significant differences for Sk among entries within seasons with consistently higher kernel weight under high available water, comparing to low available water environments. The susceptibility index, based on kernel weight (Sk) for different seasons, was reported in Table 13, where drought tolerance entries, with low relative reduction in SK values, were lower than one in the referred environments.

A season- to - season comparison of the genotypic SK values indicated some consistency, where most of the genotypes consistency tended to have $\mathrm{Sk}$ values lower or higher than one ( Table 13).

There was a negative correlation (not significant) between Tc and SK values in the two seasons. This could be explained by the high ability of the high yielding cultivars to keep a high rate of evapotranspiration and, consequently, low Tc under such stress conditions (Table 17), McCaig and Romagosa (1989).

There was a significant positive correlation only, in the second season, between SK and ELWL, while, there was a non significant correlation in the first season (Table 17). These results could be attributed to the higher level of precipitation in the first season, compared to the second one (Fig.2).

Table 16. Genotypic mean kernel weight $(\mathrm{mg})$ as affected by soil moisture, genotypes and genotype $x$ soil moisture interaction in 2004/2005 season

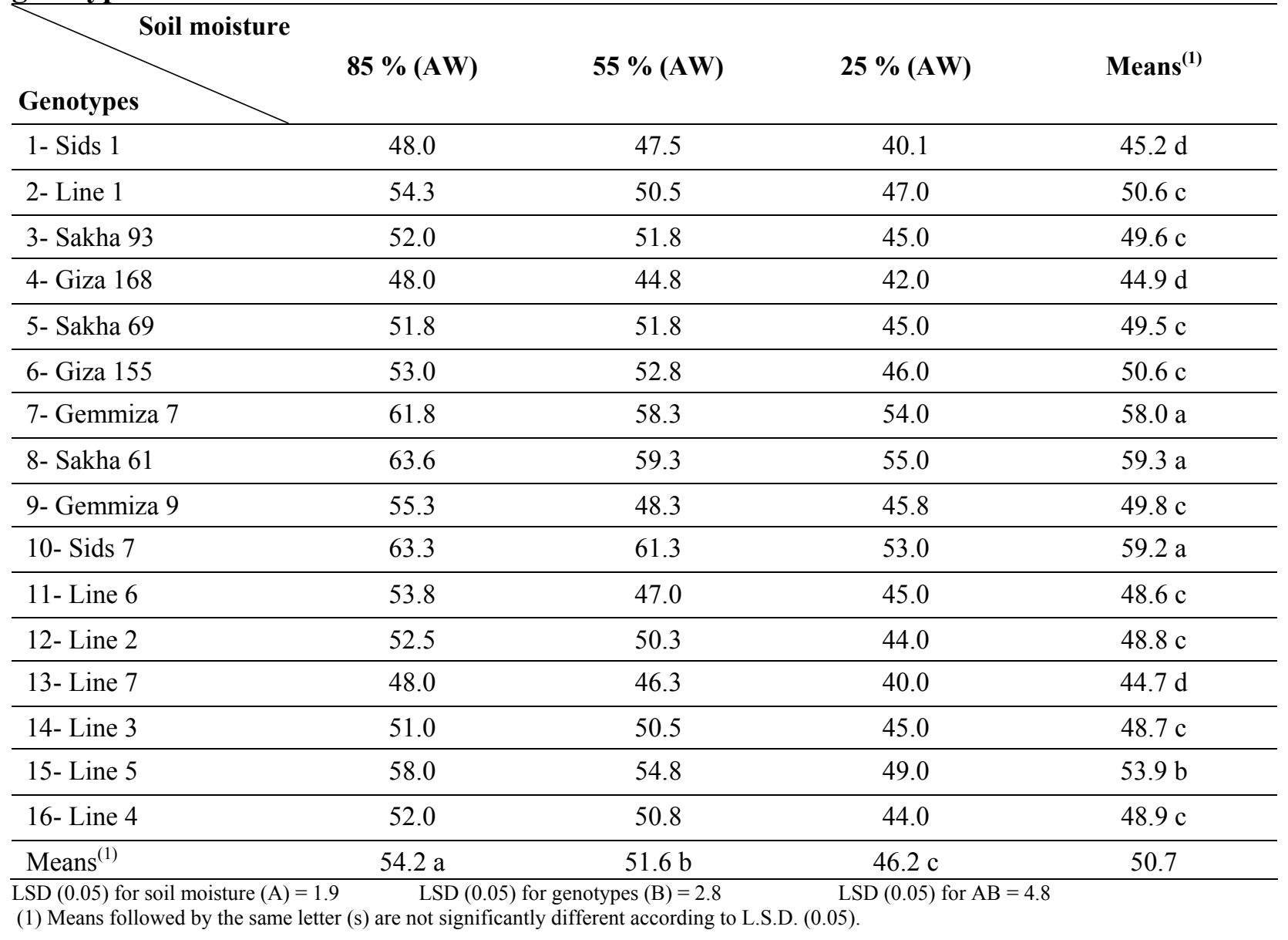


Table 17. Rank and rank correlation of kernel weight susceptibility index, canopy temperature and excised leaf water loss

\begin{tabular}{|c|c|c|c|c|c|c|c|c|}
\hline \multirow[b]{2}{*}{ Genotypes } & \multicolumn{2}{|c|}{$2003 / 2004$} & \multicolumn{2}{|c|}{$2004 / 2005$} & \multicolumn{2}{|c|}{$2003 / 2004$} & \multicolumn{2}{|c|}{$2004 / 2005$} \\
\hline & Sk & Tc & Sk & Tc & Sk & ELWL & Sk & ELWL \\
\hline 1- Sids 1 & 11 & 9 & 11 & 8 & 11 & 11 & 11 & 12 \\
\hline 2- Line 1 & 4 & 8 & 5 & 10 & 4 & 9 & 5 & 10 \\
\hline 3- Sakh 93 & 2 & 6 & 6 & 6 & 2 & 5 & 6 & 4 \\
\hline 4- Giza 168 & 6 & 12 & 1 & 12 & 6 & 4 & 1 & 6 \\
\hline 5- Sakha 69 & 1 & 9 & 3 & 9 & 1 & 3 & 3 & 3 \\
\hline 6- Giza 155 & 8 & 3 & 4 & 1 & 8 & 7 & 4 & 9 \\
\hline 7- Gemmiza 7 & 3 & 11 & 2 & 11 & 3 & 2 & 2 & 2 \\
\hline 8- Sakha 61 & 7 & 10 & 6 & 10 & 7 & 1 & 6 & 1 \\
\hline 9- Gemmiza 9 & 14 & 7 & 13 & 7 & 14 & 5 & 13 & 7 \\
\hline 10- Sids 7 & 10 & 1 & 10 & 2 & 10 & 10 & 10 & 5 \\
\hline 11- Line 6 & 5 & 13 & 12 & 11 & 5 & 13 & 12 & 3 \\
\hline 12- Line 2 & 13 & 8 & 10 & 7 & 13 & 14 & 10 & 12 \\
\hline 13- Line 7 & 5 & 2 & 11 & 3 & 5 & 12 & 11 & 13 \\
\hline 14- Line 3 & 9 & 6 & 9 & 6 & 9 & 6 & 9 & 11 \\
\hline 15- Line 5 & 11 & 5 & 8 & 5 & 11 & 6 & 8 & 3 \\
\hline 16- Line 4 & 12 & 4 & 7 & 4 & 12 & 8 & 7 & 8 \\
\hline Rank correlatio & & 0.3 & & 0.3 & & 0.32 & & 0.37 \\
\hline
\end{tabular}

* Significant at 0.05 level.

\section{REFERENCES}

Ahmad, R., J. C. Stark, N. Ahmad and A. Tanveer. (1998). Grain yield and yield components of spring wheat genotypes at different moisture regimes.Univ.J.for Scientific Res. Agric. Sci. 3: 13-19.

Balota, M. (1995). Excised-leaf water status in Romania and foreign winter wheat cultivars. Romania Agric. Res. 3: 6976.

Black, C.A., D. D. Evans and F.E. Clark (1965). Methods of Soil Analysis (Chemical and Microbiolocal Properties, part 2). American Society of Agronomy. Inc-Publisher, Madison, Wisconson, USA.

Choudhury, B. J. and S. B. Idso. (1985). Evaluating plant and canopy resistances of field-grown wheat from concurrent diurnal observations of leaf water potential, stomatal resistance, canopy temperature and evapotranspiration flux. Agricultural and Forest Meteorology 34: 67-76.

Clarke, J. M., I. Romagosa, S. Jana, J.P. Srivastava and T. N. Mccaig. (1989). Relationship of excised-leaf water loss rate and yield of drought wheat in diverse environments. Can. J. Plant Sci. 69: 1075-1081.

Dawood, R. A., K. A. Kheiralla and E. E. Mahdy. (1988). Evaluation of some wheat cultivars for drought tolerance under three levels of soil available water. Assiut. J. Agri. Sci. 19: 83-95.

Dedio. J.W .(1975). Water relations in wheat leaves as screening tests for drought resistance. Can. J. Plant Sci. 55: 369-378.

Dencic, S., R. Kastori, B. Kobijski and B. Duggan. (2000). Evaluation of grain yield and its components in wheat cultivars and landraces under near optimum and drought conditions.Euphytica 113: 43-52.
Desalegn, D., G. Bedada, A. Zewdie and S. Gelalcha. (2001). Drought tolerance of some bread wheat genotypes in Ethiopia. African Crop Sci. J: 385-392.

Donnelly, K. J. (1983). Physiological studies related to grain yield in winter wheat. Ph. D. Diss., Colorado Stat Univ., Ft. Collins, Col., USA.

Dragavtsev, V. A., G. V. Udovenko, Z. A. Shchedring and A. A. Stepanova. (1999). How the most important ecological and genetic productivity systems are manifested in wheat under various conditions of supplying water to the plants. Russian Agric.Sci.1:1-7.

El-Nagar, G. R., K. A. Kheralla and A. A. Ismail. (1997). Drought tolerance and stability of some spring wheat cultivars. Assiut J. of Agric. Sci. 28: 75-88.

Farshadfar, E., M. Ghanadha, M. Zahravi and J. Sutka. (2001). Generation mean analysis of drought tolerance in wheat. Acta Agron. Hungarica 49: 59-66.

Fisher, R. A. and R. Maurer. (1978). Drought resistance in spring wheat cultivars: I. Grain yield responses. Aust. J. Agric. Res. 29: 897-912.

Ghandorah, M. O.(1989). Response of durum wheat (Triticum turgidum L., var. durum) varieties to moisture stress under arid conditions. Arab Gulf Journal of Scientific Research 7: $15-25$.

Gomez, K. A. and A. A. Gomez. (1984). Statistical Procedures for Agricultural Research. John Wiley \& Sons, New York, U.S.A.

John M., C, Thomas and N. McCaig. (1982). Excised-leaf water retention capability as an indicator of drought resistance of Triticum genotypes. Can. J. Plant Sci. 62: 571-578. 
Journal of Agricultural Statistics. (2009). Ministry of Agriculture, Giza, Egypt.

Kheiralla, K. A., M. M Defrawy and T. H. I. Sherif. (1993). Genetic analysis of grain yield, biomass and harvest index in wheat under drought stress and normal moisture conditions. Assiut. J. of Agri. Sci. 28: 75-88.

Losavio, N., M. Mastrorilli and M. E. V. Scarascia. (1984). Leaf water potential, stomatal resistance and canopy temperature of rainfed and irrigated durum wheat. Annali Dell Istituto Sperimentale Agronomico 15: 93-116.

McCaig, T. N. and I. Romagosa. (1989). Measurement and use of excised-leaf water status in wheat. Crop Sci. 29: 1140-1145.

Saadalla, M. M and A. A. Alderfasi. ( 2000). Infrared-thermal sensing as a screening criterion for drought tolerance in wheat. Annals Agric. Sci. 45: 421-437. Ain-Shams Univ. Cairo, Egypt.
SAS Institute. (1985). SAS User's Guide; Statistical. $5^{\text {th }}$ ed. SAS Inst., Cary, NC.

Shalaby, E. E., M. M. EL.Ganbeehy and M. H. El-Sheikh. (1992). Performance of wheat genotypes under drought stress. Alex. J. Agric. Res. 37: 33-51.

Siddique, M. R. B., A. Hamid and M. S. Islam. (2000). Drought stress effects on water relations of wheat. Botanical Bulletin of Academia Sinica 41: 35-39.

Singh, V. P., M. Singh, R. Singh and M. S. Kairon. (1985). Canopy temperature of wheat under different soil moisture conditions. Indian J. of Ecology 12: 261-266.

Wang, H J. M. (1993). Relationships of excised-leaf water loss and stomatal frequency in wheat. Canadian J. of Plant Sci. 73: 93-99. 


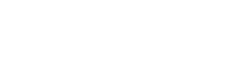

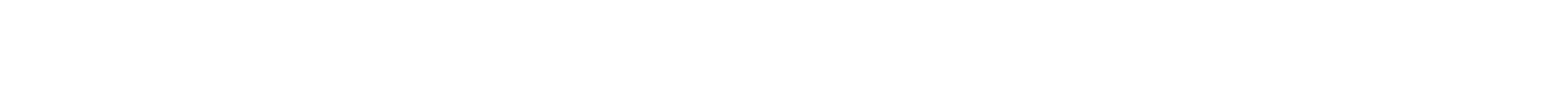

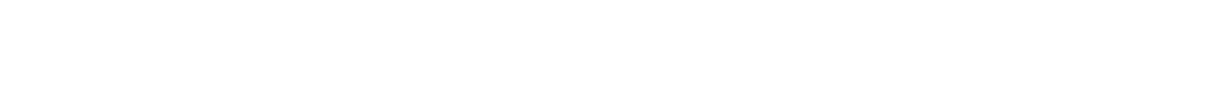

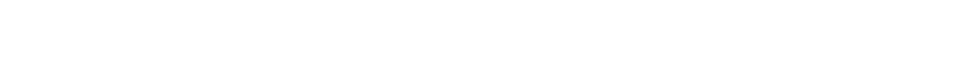

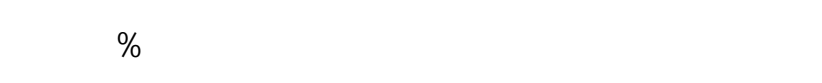

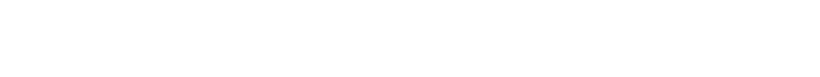

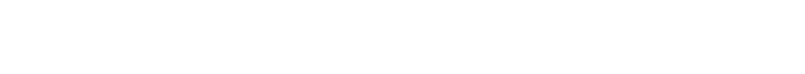

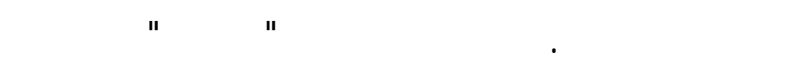

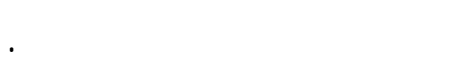

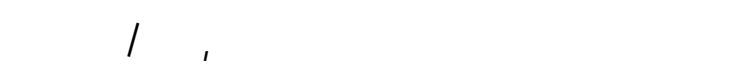
عـ,"ّل/هكنار كمتوطط لكلا مويل الدرلسة وذلك بزياة

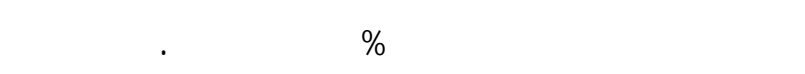

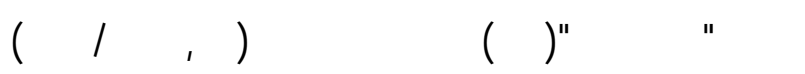

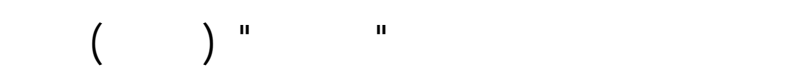

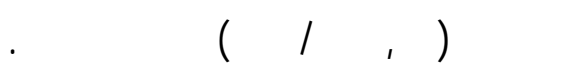

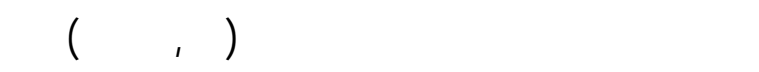

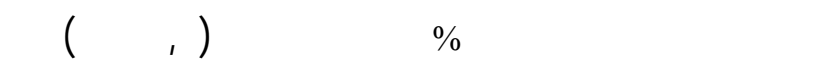

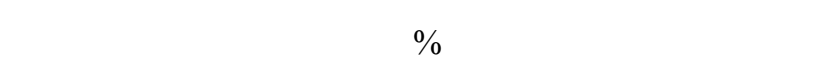

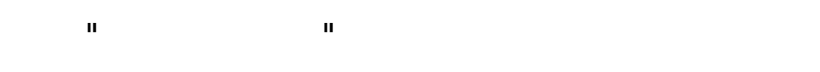

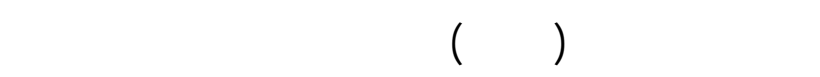

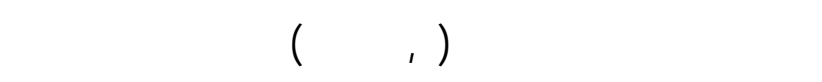

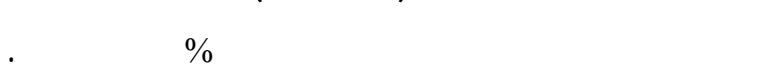

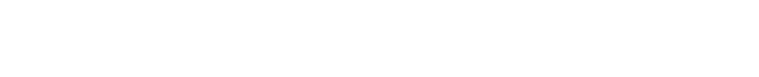

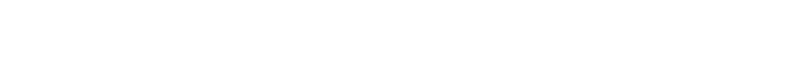

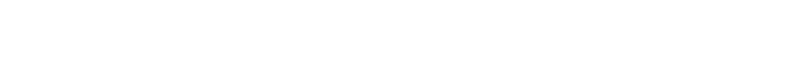

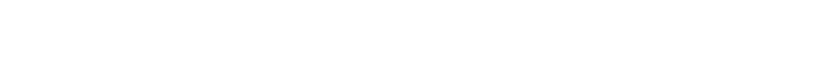

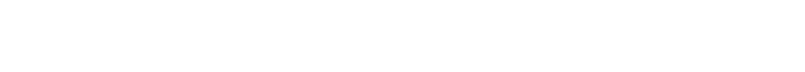

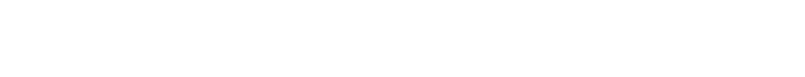
الدرلسة.
أجريت لريتل حقليتل بالمرية البحثة لكلة الزراكة جلمعة

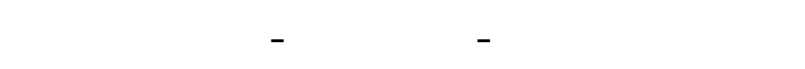

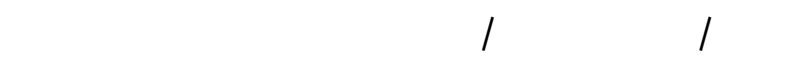

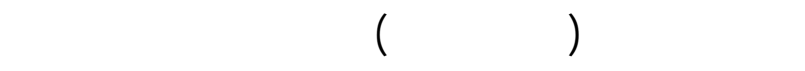

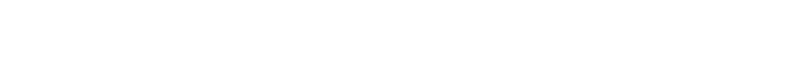

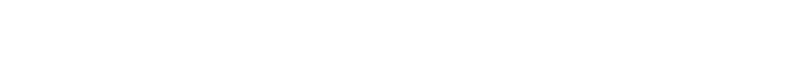

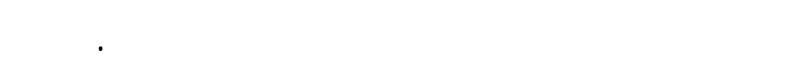

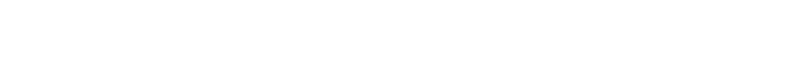

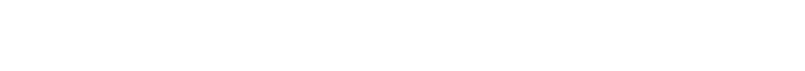

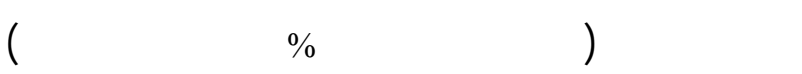
يبما وزيكت التزاكيب الوراثة عشوائيا لـالتطع الفرعية.

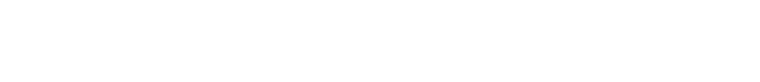

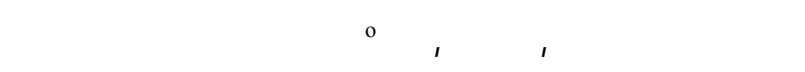

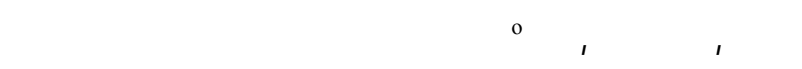

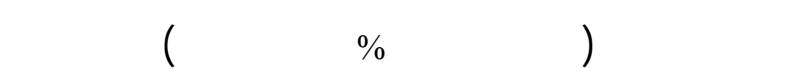

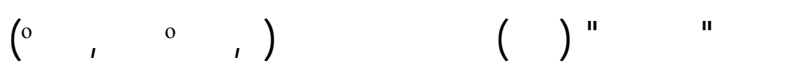

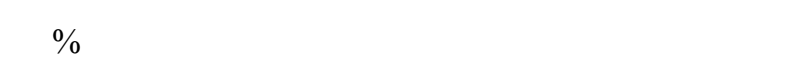

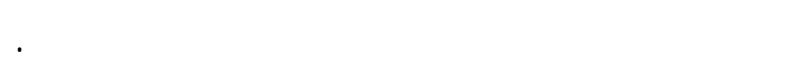

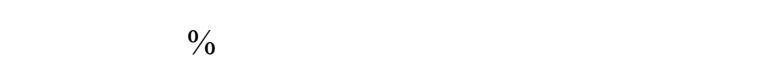

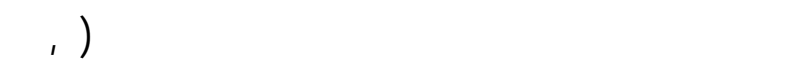

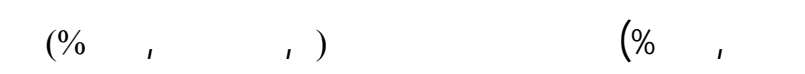

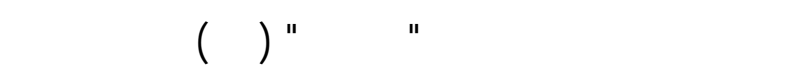

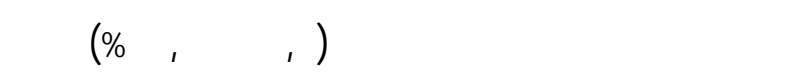

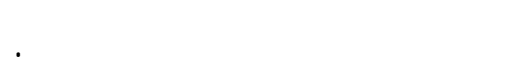

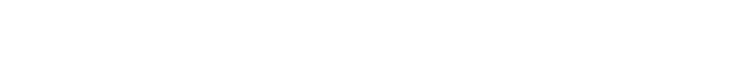

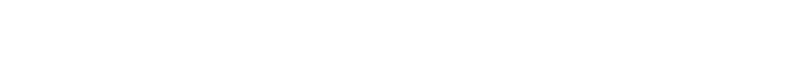

